\title{
A strontium and neodymium isotopic study of Apollo 17 high-Ti mare basalts: Resolution of ages, evolution of magmas, and origins of source heterogeneities
}

\author{
James B. PaCes, ${ }^{1, *}$ Shun'ichi Nakal, ${ }^{2}$ Clive R. Neal, ${ }^{1}$ Lawrence A. Taylor, ${ }^{1}$ AleX N. Halliday, ${ }^{2}$ and D-C. LeE ${ }^{2}$ \\ ${ }^{1}$ Department of Geological Sciences, University of Tennessee, Knoxville, TN 37996-1410, USA \\ ${ }^{2}$ Department of Geological Sciences, University of Michigan, Ann Arbor, MI 48109-1063, USA
}

(Received September 27, 1990; accepted in revised form April 25, 1991)

\begin{abstract}
A combined $\mathrm{Sr}$ and $\mathrm{Nd}$ isotopic study of 15 Apollo 17 high-Ti mare basalts was undertaken to investigate geochronological and compositional differences between previously identified magma types (A, B1, B2, and C). Whole-rock and mineral separates for one of the least-evolved Type B1 basalts, 70139, yield $\mathrm{Sm}-\mathrm{Nd}$ and $\mathrm{Rb}-\mathrm{Sr}$ isochron ages of $3.71 \pm 0.12 \mathrm{Ga}$ and $3.65 \pm 0.13 \mathrm{Ga}$, respectively. A more-evolved, Type A basalt, 71539, exhibits a slightly older $\mathrm{Sm}-\mathrm{Nd}$ isochron age of $3.75 \pm 0.07 \mathrm{Ga}$ and a $\mathrm{Rb}$-Sr isochron age of $3.67 \pm 0.10 \mathrm{Ga}$. Although these two ages are non-resolvable by themselves, compilation of all available geochronological data allows resolution of Type A and B1/B2 ages at high levels of confidence $(>99 \%)$. The most reliably dated samples, classified according to their geochemical type, yield weighted average ages of $3.75 \pm 0.02 \mathrm{Ga}$ for Type $\mathrm{A}(N=4)$ and $3.69 \pm 0.02 \mathrm{Ga}$ for Type B1/B2 $(N=3)$ basalts. Insufficient geochronological data are available to place the rare, Type $C$ basalts within this stratigraphy. We propose that age differences correlate with geochemical magma type, and that early magmatism was dominated by eruption of Type A basalts while later activity was dominated by effusion of Type B1 and B2 basalts.

Whole-rock isotopic data yield distinct differences in initial $\mathrm{Sr}$ and $\mathrm{Nd}$ isotopic compositions between Types A, B1, B2, and C basalts. Types A, B1, and C exhibit restricted intra-group compositional variations and lie along well-defined whole-rock isochrons. These data are consistent with petrogenetic models involving closed-system fractionation of observed microphenocrysts from chemically and isotopically distinct parental magmas. In contrast, a wide range of Type B2 initial isotopic compositions indicates mixing of several distinct components during magma evolution.

The Sm-Nd whole-rock isochron age for Type A, B1, and C basalts of $3.79 \pm 0.15 \mathrm{Ga}$ is within error of Apollo 17 eruptive activity. However, the very well-defined $\mathrm{Sr}$ whole-rock isochron age of $4.02 \pm 0.05$ $\mathrm{Ga}$ is 270 to $330 \mathrm{Ma}$ older than eruptive ages. Isotopic and petrological arguments indicate that extensive $\mathrm{Rb} / \mathrm{Sr}$ fractionation did not occur at the time of melt generation. Therefore, the $4.0 \mathrm{Ga} \mathrm{Sr}$ whole-rock isochron age records a significant event at which time geochemical heterogeneities were established within the originally homogeneous basalt source regions. Types $\mathrm{A}$ and $\mathrm{C}$ sources were enriched in $\mathrm{Rb} / \mathrm{Sr}$, with little or no concurrent modification of ${ }^{87} \mathrm{Sr} /{ }^{86} \mathrm{Sr}, \mathrm{Sm} / \mathrm{Nd}$, or ${ }^{143} \mathrm{Nd} /{ }^{144} \mathrm{Nd}$. Infiltration of similar-aged KREEP magmas into mantle cumulate sources cannot explain both $\mathrm{Sr}$ and $\mathrm{Nd}$ isotopic data. Instead, we suggest a metasomatic origin in which $\mathrm{Rb}$, transported as a chloride complex in halogen-rich fluids, was preferentially mobilized relative to $\mathrm{Sr}$ and the REEs.
\end{abstract}

\section{INTRODUCTION}

MAJOR-ELEMENT, TRACE-ELEMENT, AND isotopic studies of a wide variety of lunar mare basalts have led to the popularity of petrogenetic models requiring remelting of cumulates that formed during crystallization of a global magmasphere. Much of the first-order compositional variation among mare basalt groups can be attributed to gross, modal differences within cumulate layers constituting the mantle source regions. However, the more-limited compositional variations observed within an individual suite of basalts are often attributed to magmatic processes such as varied degrees of partial melting and closed-or open-system magmatic differentiation. These processes obscure the unambiguous identification of different primary melts which may, in turn, be related to small-scale heterogeneities within a particular mare basalt source region. In addition to the problem of resolving the scale of chemical

* Present address: Branch of Isotope Geology, US Geological Survey, Mailstop 963, Denver Federal Center, Denver, CO 80225, USA. variability within individual source regions, stratigraphic resolution within a single suite of lavas is severely limited by the difficulties in lowering uncertainties associated with mare basalt age determinations to below about $80 \mathrm{Ma}$.

A large suite of Apollo 17 high-Ti mare basalts analyzed to date show overall compositional similarities; however, detailed studies reveal subtle patterns of systematic differences. Three distinct geochemical magma types have been identified as Types A, B, and C high-Ti basalts (WARNER et al., 1975, 1979; RHODES et al., 1976; NEAL et al., 1990a). Using an expanding geochemical data base, NEAL et al. (1990a) have further divided Type $\mathrm{B}$ basalts into $\mathrm{B} 1$ and $\mathrm{B} 2$ compositional types on the basis of trace-element ratios. An additional variant of high-Ti basalt, termed Type D and represented by a single sample $(70091,2161)$, has REE abundances and patterns similar to Type $\mathrm{Bl}$ basalts, but distinct $\mathrm{MgO}, \mathrm{Cr}_{2} \mathrm{O}_{3}$, and $\mathrm{TiO}_{2}$ contents and warrants a distinct lineage (RYDER, 1990). Previous studies have underscored the importance of near-surface fractionation of olivine, spinel, and $\mathrm{Ti}$ oxides during petrogenesis (LONGl et al., 1974; GREEN et al., 1975; 
WARNER et al., 1975, 1979; PAPIKE et al., 1976; RHODES et al., 1976; NEAL et al., 1990a). Although overall major-element similarities between the three basalt groups suggest closely related source compositions, trace-element arguments require separate parent magmas derived from distinct source areas for each compositional type (SHIH et al., 1975; RHODES ct al., 1976; WARNER et al., 1979; NEAL et al., 1990a). In addition, WARNER et al. (1979) argued that varied degrees of partial melting were also required to explain $\mathrm{La} / \mathrm{Sm}$ variations in Type B basalts (Fig. 1), whereas these same chemical trends have been attributed to assimilation of KREEP (NEAL et al., 1989). While radiogenic isotope geochemistry should have the potential to discriminate among these various petrogenetic models, earlier $\mathrm{Sr}$ isotopic work of NYQUIST et al. (1974, $1975,1976)$ did not allow resolution of either ages or initial ${ }^{87} \mathrm{Sr} /{ }^{86} \mathrm{Sr}$ ratios between Types A and B mare basalts, though ages and $\mathrm{Sr}$ isotopic compositions of $\mathrm{Rb}$-rich, Type $\mathrm{C}$ basalts were shown to be distinct (NYQUIST et al., 1976). The lack of isotopic resolution was due, in part, to the restricted compositional range of high-Ti basalts that had been identified during the mid-1970s (Fig. 1). Subsequent geochemical studies have greatly increased both major- and trace-element compositional ranges of each of the geochemical types of Apollo 17 high-Ti basalts. The expanded geochemical database currently available requires re-examination of isotopic variations within the Apollo 17 mare basalt suite. In addition, only a small number of $\mathrm{Nd}$ isotopic analyses of Apollo 17 high-Ti basalts are presently available, and in only a few cases have both $\mathrm{Nd}$ and $\mathrm{Sr}$ isotopic compositions been acquired from the same sample. Previous Nd studies that included Apollo 17 basalts (LUGMAIR et al., 1975; NYQUIST et al., 1979; UNRUH et al., 1984) focused on Moon-wide, mare basalt comparisons and have not concentrated on compositional differences within the Apollo 17 suite.

In this study, we present high-precision $\mathrm{Rb}-\mathrm{Sr}$ and $\mathrm{Sm}-\mathrm{Nd}$ isotopic data for a set of Apollo 17 samples chosen to span

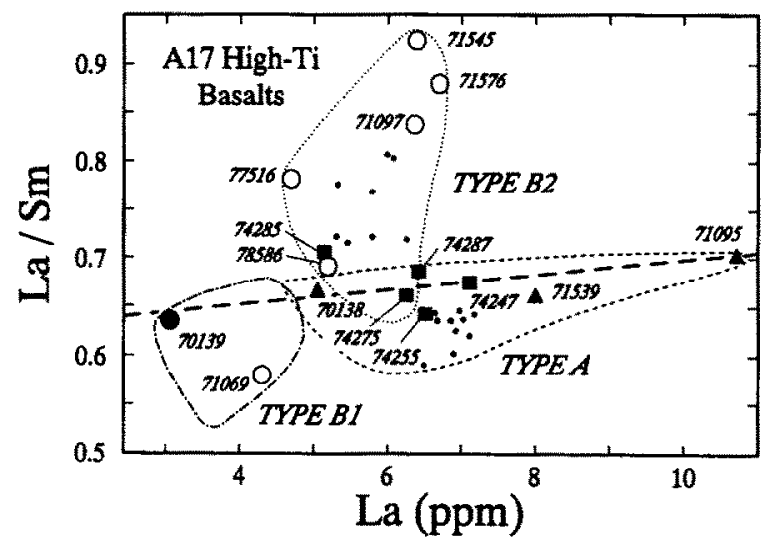

Fig. 1. $\mathrm{La} / \mathrm{Sm}$ versus $\mathrm{La}$ for samples analyzed for $\mathrm{Sr}$ and $\mathrm{Nd}$ isotopes in this study (data from RHODEs et al., 1976; WARNER et al., 1975, 1979; Mural et al., 1977; NEAL et al., 1990a). Solid triangles = Type A basalt; solid circle $=$ Type B1 basalt; open circles $=$ Type B 2 basalt; and solid squares = Type $C$ basalt. Small dots represent basalts analyzed for Rb-Sr isotopes in the mid-1970s (NYQUIST et al., 1974, 1975, 1976). Bold, dashed line indicates sub-horizontal trend of $\mathrm{La}$ $\mathrm{Sm}$ in Types $\mathrm{A}, \mathrm{Bl}$, and $\mathrm{C}$ basalts. Field boundaries from NEAL et al. (1990a). the range of each of the previously defined geochemical types. Our objectives are to ascertain whether or not resolvable age and compositional relationships exist among the different basalt types, and to determine whether observed differences are related to post-melt magma modifications or to heterogeneities within distinct Apollo 17 high-Ti basalt sources. In order to address these questions, we present two new $\mathbf{R b}-\mathrm{Sr}$ and $\mathrm{Sm}-\mathrm{Nd}$ internal isochron ages on basalts of unambiguous geochemical type. These data, combined with previously published ages, suggest that Apollo 17 volcanism was initially dominated by eruption of Type A basalts which gave way to later predominance of Type B basalts. We also present 15 new whole-rock $\mathrm{Sr}$ and $\mathrm{Nd}$ isotopic analyses which are used to test petrogenetic models. Subtle isotopic compositional variations observed between Types $\mathrm{A}, \mathrm{B} 1$, and $\mathrm{C}$ magmas are used to provide further constraints on the composition and geochemical evolution of the Apollo 17 high-Ti mantle source regions.

\section{SAMPLING AND ANALYTICAL PROCEDURES}

Basalts from each of the three geochemical groups exhibit a variety of textures which have been described in previous petrographic studies (PAPIKE et al., 1974; Brown et al., 1975; DYMEK et al., 1975; WARNER et al., 1975; NEAL. et al., 1990a). The two predominant textural types of basalt analyzed in this study are fine-grained $(<1 \mathrm{~mm})$ olivine microporphyritic, and relatively coarse-grained $(>2 \mathrm{~mm}$ ) plagioclasepoikilitic varieties. Mineralogy is dominated by pinkish-brown pyroxene (titan-augite followed by pigeonite), plagioclase, and ilmenite.

Samples consisted of basalt fragments, small chips, or homogeneous fines weighing $150-750 \mathrm{mg}$ which were coarsely crushed in a boron carbide mortar under a laminar flow of better than class 10 cleanroom quality air. Representative whole-rock samples were obtained by quarter-splitting an approximately $100 \mathrm{mg}$ aliquot which was further powdered. Two samples, 70139,6 and 71539,6 , were chosen for mineral isochron dating. 70139 is a Type B1 basalt with a relatively coarse-grained, plagioclase-poikilitic texture. A $445 \mathrm{mg}$ fragment was repeatedly crushed and sieved to coarse $(100-250 \mu \mathrm{m})$ and fine $(50$ $100 \mu \mathrm{m})$ size fractions. Washed particles were separated into four magnetic fractions, and further hand-picking of coarse fractions resulted in pure ilmenite $(\mathrm{Ilm})$ and pyroxene $(P x)$ separates. Coarse magnetic ( Mag; pyroxene + ilmenite) and non-magnetic ( $N M a g$; plagioclase + pyroxene) composite fragments, as well as the fine nonmagnetic ( F Plg; $>95 \%$ plagioclase) fraction were also analyzed. 71539 is a Type A basalt exhibiting a fine-grained, olivine microporphyritic texture, and weighing $759 \mathrm{mg}$. After removal of the whole-rock aliquot, the remaining material was treated similarly to 70139 . The finer grain-size of 71539 required crushing of all material to 50-100 $\mu \mathrm{m}$ size fraction. Similar magnetic separates were treated with heavy liquids followed by hand-picking to yield two plagioclase $(P l g l, P l g 2)$ one pyroxene $(P x I)$, and two ilmenite $(I \mathrm{Iml}, I \mathrm{Im} 2)$ fractions, as well as magnetic (Magl) and non-magnetic (NMagl) mixtures. All fractions were picked under spectrographic-grade methanol and were cleaned by cold, ultrasonic washes in methanol, distilled acetone, and deionized water. Mineral separates weighed between 7 and 58 $\mathrm{mg}$, and each separate was total-spiked before digestion with known ${ }^{87} \mathrm{Rb},{ }^{84} \mathrm{Sr},{ }^{149} \mathrm{Sm}$, and ${ }^{150} \mathrm{Nd}$ tracers. Whole-rock samples weighing between 37 and $68 \mathrm{mg}$ were first dissolved, after which solutions were split into unspiked and spiked aliquots. Two-stage cation separations followed standard techniques described elsewhere (HALLIDAY et al., 1989). Average total-process blanks for chemical procedures were 20 $\mathrm{pg} \mathrm{Rb}, 70 \mathrm{pg} \mathrm{Sr}, 17 \mathrm{pg} \mathrm{Sm}$, and $70 \mathrm{pg} \mathrm{Nd}$.

Isotopic data were obtained on VG Sector multicollector thermal ionization mass spectrometers. Strontium was loaded, along with $\mathrm{Ta}_{2} \mathrm{O}_{3}$ powder, onto single $\mathrm{Re}$ filaments while $\mathrm{Rb}$ was loaded onto triple Ta filament assemblies. Samarium and neodymium were loaded onto triple Ta-Re-Ta filament assemblies, and both were measured as metal ions. Isotope dilution measurements were made using static simultaneous multicollection of $40-80$ ratios. Strontium and neo- 
TABLE 1: $\mathrm{Rb}-\mathrm{Sr}$ and Sm-Nd analytical results for whole rocks and mineral separates used for internal isochrons.

\begin{tabular}{|c|c|c|c|c|c|c|c|c|c|}
\hline Sample & Wt.(mg) & $\begin{array}{c}\mathbf{R b} \\
(\mathbf{p p m})\end{array}$ & $\begin{array}{c}\mathrm{Sr} \\
(\mathrm{ppm}) \\
\end{array}$ & ${ }^{87} \mathrm{Rb} /{ }^{86} \mathrm{Sr}^{a}$ & ${ }^{87} \mathrm{Sr} r^{86} \mathrm{Sr}^{b}$ & $\begin{array}{c}\text { Sm } \\
\text { (ppm) }\end{array}$ & $\begin{array}{c}\text { Nd } \\
\text { (ppm) }\end{array}$ & ${ }^{147} \mathrm{Sm} / /^{144} \mathrm{Nd}^{a}$ & ${ }^{143} \mathrm{Nd} / 1^{144} \mathrm{Nd}^{b}$ \\
\hline \multicolumn{10}{|c|}{70139,6 Type B1 } \\
\hline WR1 & 66.90 & 0.281 & 146 & $0.005515_{ \pm} 55$ & $0.699511 \pm 14$ & 5.30 & 12.3 & $0.26021 \pm 52$ & $0.514547_{ \pm 11}$ \\
\hline WR2 & 65.28 & 0.282 & 146 & $0.005543_{ \pm} 55$ & $0.699518 \pm 17$ & 5.38 & 12.4 & $0.26234 \pm 52$ & $0.514605_{ \pm} 15$ \\
\hline F Plg & 8.80 & 0.0886 & 514 & $0.004956 \pm 20$ & $0.699244 \pm 27$ & & & & \\
\hline $\operatorname{llm}$ & 16.83 & 0.313 & 23.1 & $0.03903 \pm 39$ & $0.701312 \pm 31$ & 3.49 & 8.54 & $0.24726 \pm 49$ & $0.514230_{ \pm} 23$ \\
\hline $\mathbf{P x}$ & 37.42 & 0.143 & 30.2 & $0.01364 \pm 14$ & $0.699922 \pm 32$ & 4.85 & 9.72 & $0.3020 \pm 15$ & $0.515571 \pm 29$ \\
\hline $\mathrm{Mag}^{c}$ & 46.23 & 0.478 & 87.9 & $0.01564 \pm 16$ & $0.700013 \pm 28$ & 9.17 & 21.5 & $0.2574 \pm 26$ & $0.514457_{ \pm} 25$ \\
\hline NMag $^{c}$ & 28.60 & 0.0882 & 270 & $0.000939_{ \pm} 18$ & $0.699297 \pm 25$ & 1.82 & 3.89 & $0.28250 \pm 56$ & $0.515098 \pm 26$ \\
\hline \multicolumn{10}{|c|}{ 71539,6 Type A } \\
\hline WR & 36.93 & 0.787 & 229 & $0.009893+98$ & $0.699776+14$ & 13.4 & 32.5 & $0.25018 \pm 50$ & $0.514306 \pm 11$ \\
\hline Plg1 & 30.54 & 0.260 & 623 & $0.001199 \pm 11$ & $0.699336 \pm 22$ & 2.08 & 5.70 & $0.2204 \pm 22$ & $0.513565 \pm 19$ \\
\hline Plg2 & 12.13 & 0.594 & 536 & $0.003192 \pm 31$ & $0.699382 \pm 20$ & 5.91 & 15.2 & $0.2352 \pm 24$ & $0.513899 \pm 20$ \\
\hline $\mathrm{NMagl}^{c}$ & 19.45 & 0.188 & 253 & $0.002139_{ \pm} 21$ & $0.699360_{ \pm} 21$ & & 9.20 & & $0.513868 \pm 20$ \\
\hline Pxl & 43.86 & 0.121 & 58.7 & $0.005917 \pm 59$ & $0.699564 \pm 22$ & 5.12 & 9.22 & $0.3362 \pm 17$ & $0.516428 \pm 18$ \\
\hline $\operatorname{Magl}^{c}$ & 57.70 & 0.573 & 103 & $0.01602 \pm 32$ & $0.700119_{ \pm 20}$ & & & & $0.514780_{ \pm} 16$ \\
\hline $\mathrm{Ilm} 1$ & 8.89 & 1.23 & 104 & $0.03395 \pm 34$ & $0.701188 \pm 20$ & 18.4 & 38.3 & $0.2900 \pm 14$ & $0.515283 \pm 22$ \\
\hline $\operatorname{llm} 2$ & 6.87 & 0.642 & 128 & $0.01444 \pm 14$ & $0.700033 \pm 20$ & & 22.4 & & $0.514350_{ \pm} 19$ \\
\hline
\end{tabular}

\footnotetext{
${ }^{a}$ Uncertainties (corresponding to last decimal places) reported for parent/daughter ratios reflect the magnitude of the blank correction, mass spectrometer precision and corrections for the quality of apiking.

${ }^{b}$ Normalized to ${ }^{86} \mathrm{Sr} /{ }^{88} \mathrm{Sr}=0.1194$ and ${ }^{146} \mathrm{Nd} / /^{144} \mathrm{Nd}=0.7219$. Quoted errors include 2 sigma run precision for whole rock analyses plus an additional uncertainty of 0.00001 ( 2 sigma) reflecting corrections for fractionation and spike contributions in total-spiked mineral separates. Nd was measured as the metal ion.

c Non-pure mineral separates consisting of predominantly "nonmagnetic" plagioclase and pyroxene in NMag and "magnetic" pyroxene and ilmenite in Mag.
}

dymium isotopic compositions on unspiked aliquots were measured using multidynamic analysis of about 200 ratios with resulting precisions of $0.001-0.003 \%$ (2 sigma). All Sr and Nd analyses are normalized to ${ }^{86} \mathrm{Sr} /{ }^{88} \mathrm{Sr}=0.1194$ and ${ }^{146} \mathrm{Nd} /{ }^{144} \mathrm{Nd}=0.7219$, respectively. Fifteen analyses of NBS987 Sr and La Jolla Nd standards analyzed over the same time period yielded weighted averages of ${ }^{87} \mathrm{Sr} /{ }^{86} \mathrm{Sr}$ $=0.710251 \pm 0.000009$ and ${ }^{143} \mathrm{Nd} /{ }^{144} \mathrm{Nd}=0.511866 \pm 0.000005$. The effects of neutron bombardment lowering Sm concentrations by depletion of ${ }^{149} \mathrm{Sm}$ have been ignored in this study. NYQUIST et al. (1979) estimated a $0.2 \%$ decrease in the $\mathrm{Sm} / \mathrm{Nd}$ ratio on 75075 from the Sm isotopic measurements of LuGMaIR et al. (1975). Although varying lengths of exposure on the lunar surface for the different samples may cause some scatter, the concordance of data for all Type A, B1, and C samples on the same isochron indicates that exposure effects are not detrimental to the Sm-Nd dating technique for the present suite of rocks. Age calculations use decay constants of 6.54 $\times 10^{-12} \mathrm{yr}^{-1}$ for ${ }^{147} \mathrm{Sm}$ and $1.42 \times 10^{-11} \mathrm{yr}^{-1}$ for ${ }^{87} \mathrm{Rb}$ (STEIGER and JÄGER, 1977). Although the $1.42 \times 10^{-11} \mathrm{yr}^{-1}$ constant has become internationally accepted for all terrestrial and many extraterrestrial studies, combined isotopic studies on ancient lunar and some meteoritic materials suggest that the older $\mathrm{Rb}$-Sr ages obtained using a $1.39 \times 10^{-11} \mathrm{yr}^{-1}$ decay constant for ${ }^{87} \mathrm{Rb}$ are, in some instances, in better concordance with other isotopic systems (MINSTER et al., 1982; NYQUIST et al., 1986; SHIH et al., 1986). However, this issue is complicated by the possibility of post-magmatic mobility of $\mathrm{Rb}$ and $\mathrm{Sr}$ due to impact heating associated with sample excavation (see geochronology section). Until these factors are better understood, we prefer to use the standardized $1.42 \times 10^{-11} \mathrm{yr}^{-1}$ value for the ${ }^{87} \mathrm{Rb}$ decay constant. Two additional samples of extraterrestrial materials have been analyzed over the same time period: a coarse-grained Apollo 15 olivine tholeiite, 15555,817, and a split of the Smithsonian Allende carbonaceous chondrite meteorite standard, USNM 3529. Variations in $\mathrm{Rb}, \mathrm{Sr}, \mathrm{Sm}$, and $\mathrm{Nd}$ concentrations and present-day isotopic com- positions of replicate analyses indicate that both samples contain mineralogical inhomogeneities on the scale of the 35 to $45 \mathrm{mg}$ powders digested for analysis. However, calculated initial ratios between replicates are nearly identical, and show initial ratios and associated errors which are within error of previously published results.

\section{GEOCHRONOLOGICAL INVESTIGATION}

\section{Internal Isochron Results}

Results of isotopic analyses for 70139 and 71539 whole rocks and mineral separates are listed in Table 1 . In both cases, $\mathrm{Rb}-\mathrm{Sr}$ and $\mathrm{Sm}-\mathrm{Nd}$ isochron plots yield linear arrays of data (Figs. 2 and 3). The small range of parent/daughter ratios present in the mineral phases limits the uncertainty of the calculated ages to no better than 70 to $130 \mathrm{Ma}$. For both rocks, $\mathrm{Rb}-\mathrm{Sr}$ ages are 60 to $80 \mathrm{Ma}$ younger than $\mathrm{Sm}-\mathrm{Nd}$ ages. Although $\mathrm{Rb}-\mathrm{Sr}$ and $\mathrm{Sm}-\mathrm{Nd}$ ages for both rocks are nearly identical when the $1.39 \times 10^{-11} \mathrm{yr}^{-1}{ }^{87} \mathrm{Rb}$ decay constant is used, lower $\mathrm{Rb}-\mathrm{Sr}$ ages relative to $\mathrm{Sm}-\mathrm{Nd}$ ages are commonly observed in other studies, even when "older" $\mathrm{Rb}$-Sr ages are calculated using the $1.39 \times 10^{-11} \mathrm{yr}^{-1}$ decay constant (e.g., NyQuis I et al., 1981; SHIH et al., 1986). In addition, several of the individual mineral fractions described below show abnormal deviations of $\mathrm{Rb}-\mathrm{Sr}$ isotopic data from the best-fit regressions and may imply that the $\mathrm{Rb}-\mathrm{Sr}$ system was more easily disturbed than Sm-Nd during excavation of these two rocks. Until the Rb decay constant is better determined, Sm$\mathrm{Nd}$ ages are considered most representative of the actual 

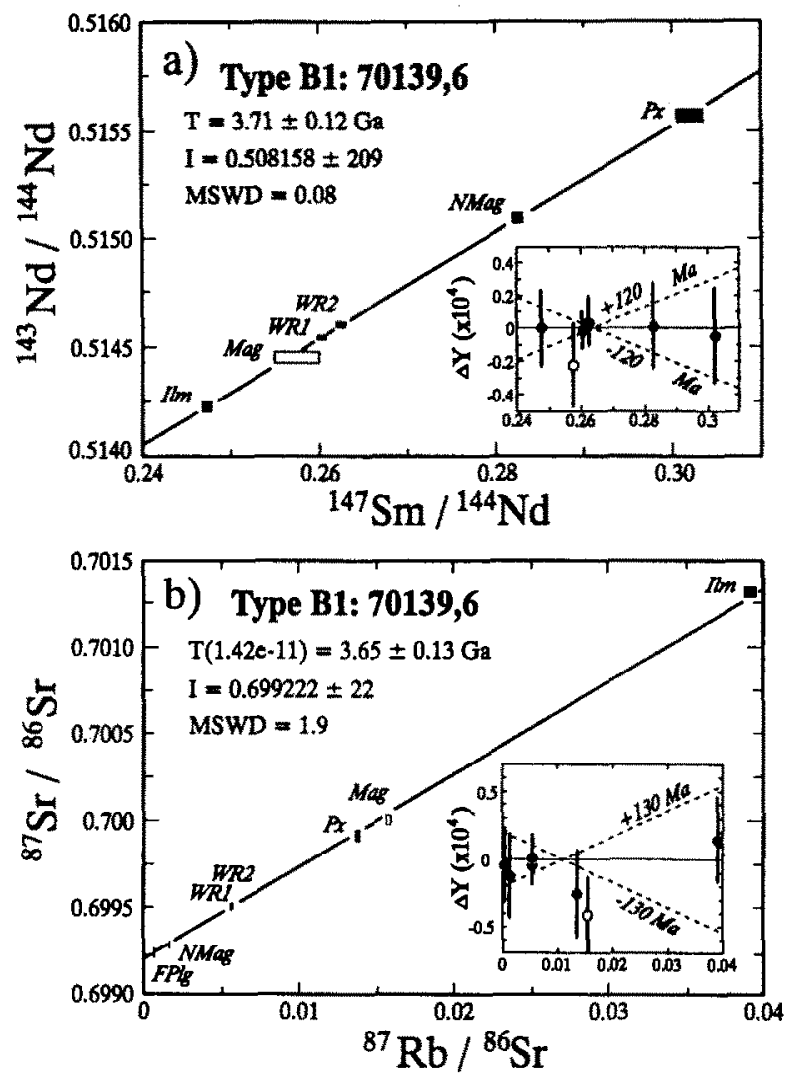

FiG. 2. (a) Sm-Nd and (b) Rb-Sr internal isochrons for 70139,6. Size of error boxes representing data points are drawn in proportion to uncertainties given in Table 1. Age and initial ratios were calculated using Model 1 York regression slope and intercept (YORK, 1969; LUDWIG, 1990). Strontium age is calculated with ${ }^{87} \mathrm{Rb}$ decay constant of $1.42 \times 10^{-11} \mathrm{yr}^{-1}\left(T=3.73 \mathrm{Ga}\right.$ using $\left.\lambda^{87} \mathrm{Rb}=1.39 \times 10^{-11} \mathrm{yr}^{-1}\right)$. Data represented by the open symbols are not included in the isochron regression. All uncertainties quoted at the $95 \%$ confidence limit. Insets show the deviations of ${ }^{143} \mathrm{Nd} /{ }^{144} \mathrm{Nd}$ and ${ }^{87} \mathrm{Sr} /{ }^{86} \mathrm{Sr}$ from the regressed isochron in parts per 10,000 along with error limits both for individual data points (error bars), and for the regression line (dashed lines).

crystallization ages. All isochrons are calculated as Model 1 regressions (based on the original algorithm of YORK, 1969) using the program of LUDWIG (1990). Uncertainties are calculated using the maximum-likelihood algorithm of TITTERINGTON and HALLIDAY (1979) and, in all cases, are reported at the $95 \%$ confidence limit. Resulting ages for each rock are examined briefly below.

\section{Type B1: 70139,6}

Sm-Nd data for all fractions (four mineral separates and two whole-rock samples, Table 1) yield an age of $3.72 \pm 0.12$ $\mathrm{Ga}$ (Fig. 2a). The regression spans a very limited range of ${ }^{147} \mathrm{Sm} /{ }^{144} \mathrm{Nd}$ values with pyroxene-rich separates at the high ${ }^{147} \mathrm{Sm} /{ }^{144} \mathrm{Nd}$ end and ilmenite-rich separates at the low end. The pyroxene + ilmenite mixed fraction ( $\mathrm{Mag}$ ) contains REE abundances which are about twice as high as either the pure pyroxene or ilmenite fractions. We suspect that this fraction includes brownish mesostasis with high REE abundances, similar in appearance to the pinkish-brown pyroxene. This is consistent with $\mathrm{Rb}$ abundances which are also higher in the $\mathrm{Mag}$ fraction than in any of the other fractions. Since the glassy portions of the rock are more likely affected by mild heating associated with post-crystallization impact and exposure processes, the presence of mesostasis in this fraction may increase the possibility of subsequent partial resetting. Regression of the data excluding the Mag fraction (i.e., WRI, $W R 2, P x, N M a g$, and $I / m$ ) results in a nearly identical age of $3.71 \pm 0.12 \mathrm{Ga}$ with a very low MSWD of 0.08 (see Fig. 2). We consider this date to be the best $\mathrm{Sm}-\mathrm{Nd}$ isochron age for 70139 .

$\mathrm{Rb}-\mathrm{Sr}$ data for all mineral fractions yield an age of 3.62 $\pm 0.15 \mathrm{Ga}$ (Fig. 2b). The ${ }^{87} \mathrm{Sr} /{ }^{86} \mathrm{Sr}$ intercept value of 0.699222 \pm 0.000022 is well defined due to the extrcmely low ${ }^{87} \mathrm{Rb} /$ ${ }^{86} \mathrm{Sr}$ values in plagioclase separates. Regression of all data results in a MSWD of 2.84 which indicates a greater amount of scatter from the best-fit regression relative to the $\mathrm{Sm}-\mathrm{Nd}$ isochron (inset, Fig. 2b). As noted earlier, the mixed pyroxene + ilmenite fraction, Mag, contains higher $\mathbf{R b}$ and $\mathrm{Sr}$ concentrations than either of the two mineral phases analyzed alone. This fraction falls below the best-fit regression and is suspected of containing glassy mesostasis. If the $\mathrm{Mag}$ fraction is excluded from the regression, a slightly higher age of 3.65 $\pm 0.13 \mathrm{Ga}$ is obtained with a slightly improved MSWD of 1.9. Although we cannot discount the possibility of analytical artifacts, we suspect that the observed scatter may be due to
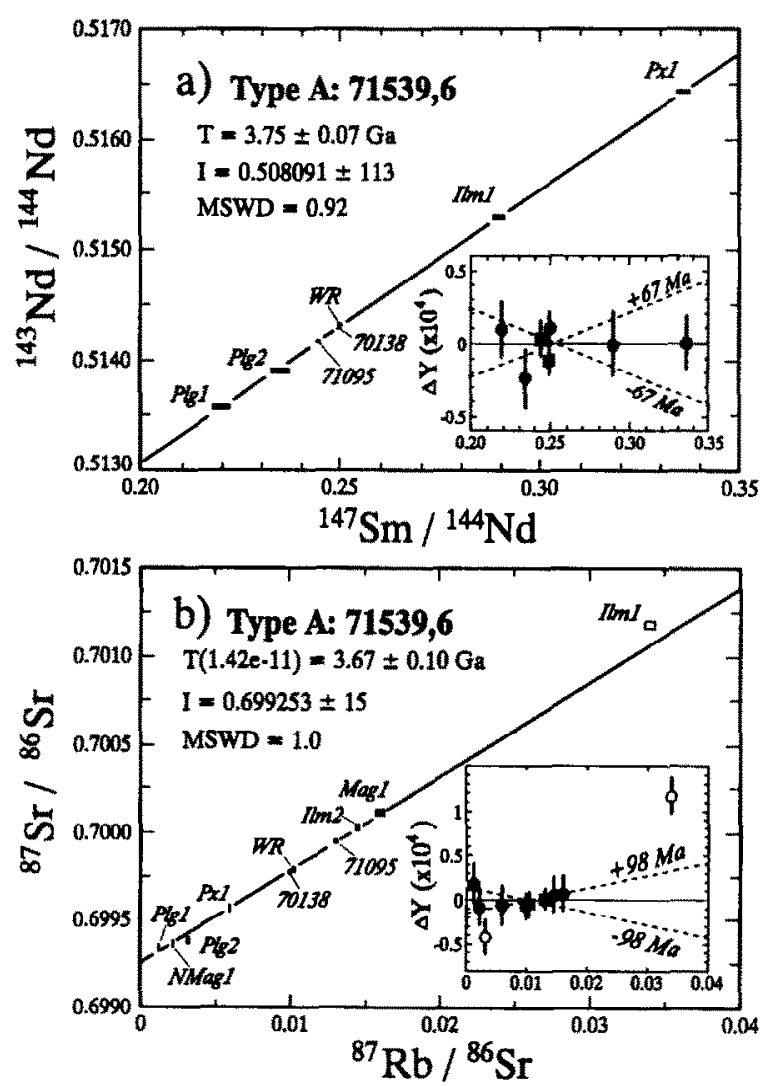

FIG. 3. (a) Sm-Nd and (b) Rb-Sr internal isochrons for 71539,6 (Sr isochron age $=3.75 \mathrm{Ga}$ using $\mathrm{\lambda}^{87} \mathrm{Rb}=1.39 \times 10^{-11} \mathrm{yr}^{-1}$ ). Details listed for Fig. 2 apply equally to Fig. 3 with the added comments: 70139 and 71095 are additional Type A whole-rock samples listed in Table 3 and have been included in the regression. See text for discussion. 
mobility of $\mathrm{Rb}$ or $\mathrm{Sr}$ on a mineral-sized scale, particularly associated with glassy mesostasis adhering to the opaque fragments. However, $\mathrm{Rb}$ and $\mathrm{Sr}$ were probably not disrupted on the larger, whole-rock scale, where a substantially moreprecise $\mathrm{Rb}$-Sr isochron is obtained from samples which span a smaller $\mathrm{Rb} / \mathrm{Sr}$ range. Although disturbances of the $\mathrm{Rb}-\mathrm{Sr}$ system have not been evident in earlier work, the improved analytical precision attainable with the new generation of mass spectrometers may permit recognition of geological errors which were previously unresolved from analytical errors.

\section{Type A: 71539,6}

Regression of all Sm-Nd data (one whole-rock and four mineral fractions, Table 1) yields an age of $3.73 \pm 0.07 \mathrm{Ga}$ (Fig. 3a). The range in ${ }^{147} \mathrm{Sm} /{ }^{144} \mathrm{Nd}$ for mineral separates from 71539 is larger than that observed for 70139 and includes two analyses for plagioclase which display the lowest ${ }^{147} \mathrm{Sm} /{ }^{144} \mathrm{Nd}$ values. Unlike $70139, \mathrm{Sm}$ and $\mathrm{Nd}$ abundances of the ilmenite fractions in 71539 are about two to four times higher than those in the pyroxene fraction. Rubidium concentration in at least one of the ilmenite fractions is also much higher than any of the other mineral separates. Although 71539 (Type A) is much more geochemically evolved than 70139 (Type B1), equilibrium partitioning of incompatible trace elements cannot explain the differences in ilmenite compositions. We suspect that the ilmenite in 71539 may be intergrown with minor amounts of mesostasis. Regardless of this possibility, the $I l m l$ fraction plots on the bestfit Sm-Nd regression line. Two additional Type A wholerock analyses, 70138 and 71095 (data in Table 3), also plot on the 71539 mineral isochron (Fig. 3a) and are most likely related. The resulting regression yields a slightly older age of $3.75 \pm 0.07 \mathrm{Ga}$ with an MSWD of 0.92 . This date, which includes a larger number of data points, is considered to represent the best $\mathrm{Sm}-\mathrm{Nd}$ age for 71539 .

$\mathrm{Rb}-\mathrm{Sr}$ isotopic data for 71539 exhibit scatter in its linear array which cannot be attributed to analytical error. Kegression of all data (one whole-rock and seven mineral analyses) yields an age of $3.83 \pm 0.17 \mathrm{Ga}$ (Fig. 3b). This Rb-Sr age is substantially older ( $80 \mathrm{Ma}$ ) than the $\mathrm{Sm}-\mathrm{Nd}$ age; however, the large uncertainties associated with the $\mathrm{Rb}-\mathrm{Sr}$ regression do not allow resolution of the two ages. Much of the excessive scatter in this regression (MSWD $=8.3$ ) can be attributed to the ilmenite fraction, $I l m 1$, and the range in isotopic compositions of the plagioclase-rich fractions. As noted earlier, the ilmenite-rich fraction is suspected of containing $\mathrm{Rb}$ - and REE-enriched mesostasis in which more-volatile $\mathrm{Rb}$ abundances may be mobilized during impact heating. In addition to $I \mathrm{ImI}$, one of the plagioclase separates, $P \lg 2$, deviates from the best-fit line more than other samples. This fraction is a smaller and less-pure separate than $P l g l$, and has substantially higher $\mathrm{Rb}$ and $\mathrm{REE}$ contents than either of the other two plagioclase-rich fractions ( $P l g 1$ and NMagl, Table 1). If this point, along with $I l m l$, is excluded from regression, an age of $3.67 \pm 0.11 \mathrm{Ga}$ is obtained with $\mathrm{I}(\mathrm{Sr})=0.699253$ \pm 0.000015 . The MSWD of 1.0 for this regression is substantially reduced. The two additional Type A whole-rock analyses (71038 and 71095, Table 3) also fall on the 71539 internal isochron (Fig. 3b). Inclusion of these two additional data points in the $\mathrm{Sr}$ regression analysis yields an age of 3.67 $\pm 0.10 \mathrm{Ga}$, which is the best estimate of the internal $\mathrm{Rb}-\mathrm{Sr}$ isochron age for 71539. Although the aberrant hehavior of IlmI and Plg2 separates may be caused by analytical artifacts, these same samples do not show excessive scatter on the Sm$\mathrm{Nd}$ isochron plot. The consistent patterns of $\mathrm{Rb}-, \mathrm{Sr}-$, and REE-enrichments in both $\mathrm{Ilm} l$ and $\mathrm{Plg} 2$ mineral fractions, combined with the well-defined $\mathrm{Sm}-\mathrm{Nd}$ isochron, suggest a geological, rather than analytical, cause for excessive $\mathrm{Rb}-\mathrm{Sr}$ scatter.

\section{Summary of ages for 70139 and 71539}

The best age estimates for the Type B1 basalt, 70139, and the Type A basalt, 71539 , are $3.71 \pm 0.12 \mathrm{Ga}$ and $3.75 \pm 0.07$ $\mathrm{Ga}$, respectively, based on the Sm-Nd internal isochrons. In both cases, the $\mathrm{Sm}-\mathrm{Nd}$ isochron ages are preferred over Rb$\mathrm{Sr}$ ages because of the slightly smaller uncertainties associated with Sm-Nd regressions, and because of the controversy surrounding the choice of the most appropriate ${ }^{87} \mathrm{Rb}$ decay constant. However, it should be noted that if an ${ }^{87} \mathrm{Rb}$ decay constant of $1.39 \times 10^{-11} \mathrm{yr}^{-1}$ is used, very good agreement exists between the two systems, providing further support of the $\mathrm{Sm}-\mathrm{Nd}$ ages. One possible explanation for discordance between $\mathrm{Sm}-\mathrm{Nd}$ and $\mathrm{Rb}-\mathrm{Sr}$ ages using the $1.42 \times 10^{-11} \mathrm{yr}^{-1}$ decay constant is that the minerals within both basalts had their Rb-Sr, but not their Sm-Nd, systematics disturbed by a younger impact event. Although none of the Apollo 17 basalts show signs of extensive shock metamorphic recrystallization, the younger Rb-Sr internal isochron ages for both rocks, plus excessive $\mathrm{Rb}-\mathrm{Sr}$ scatter observed for some mineral separates, suggest that $\mathrm{Sr}$ ages, by themselves, should be approached with caution.

Although the Type A basalt appears to be older than the Type $B 1$ basalt, uncertainties associated with each individual age determination are larger than the apparent age difference of $40 \mathrm{Ma}$. These data alone leave questions of magmatic stratigraphy and duration of volcanism at the Apollo 17 unanswered. However, in spite of the inherent difficulty in determining high-precision isochron ages on basalts exhibiting such limited variation in $\mathrm{Rb} / \mathrm{Sr}$ and $\mathrm{Sm} / \mathrm{Nd}$ ratios, uncertainties can be significantly lowered by increasing the number of observations. Examination of the larger set of published age determinations on Apollo 17 high-Ti mare hasalts is helpful towards this goal.

\section{Ages of Apollo 17 Volcanism}

Twenty-eight published $\mathrm{Rb}-\mathrm{Sr}, \mathrm{Sm}-\mathrm{Nd}$, or ${ }^{40} \mathrm{Ar}-{ }^{39} \mathrm{Ar}$ dates on fifteen different Apollo 17 mare basalts have been determined over a period from 1973 to the present study (Table 2, Fig. 4). Ages range from 3.64 to $3.84 \mathrm{Ga}$. In general, ages obtained on the same basalt by different techniques and/or by different laboratories agree within error limits of individual age determinations. For the purposes of consistency, all isochron regressions have been recalculated using the Model 1 Yorkfit routine of LUDwIG (1990), and Rb-Sr age determinations have been calculated using the $1.42 \times 10^{-11} \mathrm{yr}^{-1}{ }^{87} \mathrm{Rb}$ decay constant. This results in younger $\mathrm{Rb}-\mathrm{Sr}$ ages than previously reported due to the former use of the $1.39 \times 10^{-11}$ 
Table 2: Available geochronological data for Apollo 17 high-Ti mare basalts.

\begin{tabular}{llllll}
\hline Sample & Type & Age (Ma) & Method & \multicolumn{1}{c}{ Reference } & "Best-Age \\
Estimate (Ma)
\end{tabular}

${ }^{a} 70139$ is the only Type B sample with sufficient geochemical data to permit B1/B2 classification. Chemical type for 75083 and 79155 remains undefined due to lack data.

${ }^{b}$ All Sr and Nd isochron ages regressed using Ludwig (1990) with $\lambda^{87} \mathrm{Rb}=1.42 \times 10^{-11} \mathrm{yr}^{-1}$.

${ }^{c}$ Best estimate based on Nd iatemal isochron age.

${ }^{d}$ Best estimate based on weighted average age of multiple age determinations.

$\mathrm{yr}^{-1}$ decay constant and in slightly different uncertainties (usually higher) due to the more rigorous assessment of $95 \%$ confidence errors by the LUDWIG (1990) regression analysis. In three out of the four rocks possessing both $\mathrm{Rb}-\mathrm{Sr}$ and $\mathrm{Sm}-$ $\mathrm{Nd}$ internal isochron dates, $\mathrm{Rb}-\mathrm{Sr}$ age determinations are 60 to 100 Ma younger than the Sm-Nd ages, while, in the fourth rock, two $\mathrm{Rb}-\mathrm{Sr}$ age determinations are 60 to $80 \mathrm{Ma}$ older. In rocks with both $\mathrm{Rb}-\mathrm{Sr}$ and ${ }^{40} \mathrm{Ar}-{ }^{39} \mathrm{Ar}$ data, $\mathrm{Rb}-\mathrm{Sr}$ age determinations can be younger, older, or very similar to ${ }^{40} \mathrm{Ar}$ ${ }^{39} \mathrm{Ar}$ dates, which typically have much smaller reported uncertainties. In the only sample possessing $\mathrm{Rb}-\mathrm{Sr}, \mathrm{Sm}-\mathrm{Nd}$, and ${ }^{40} \mathrm{Ar}-{ }^{39} \mathrm{Ar}$ ages (75075), very good agreement exists between $\mathrm{Sm}-\mathrm{Nd}$ and ${ }^{40} \mathrm{Ar}-{ }^{39} \mathrm{Ar}$ ages, and between the $\mathrm{Rb}-\mathrm{Sr}$ ages determined by two separate labs; however, both $\mathrm{Sr}$ ages are older than (although within error of) the Sm-Nd and ${ }^{40} \mathrm{Ar}$ ${ }^{39} \mathrm{Ar}$ ages. This discrepancy is further exacerbated when the $1.39 \times 10^{-11} \mathrm{yr}^{-187} \mathrm{Rb}^{-3 e c a y}$ constant is used.

The existing geochronological data set underscores the need for further high-precision age determinations by multiple techniques on the same rock. However, current data is helpful in revealing general age relationships between the different geochemical basalt types. Where multiple-age determinations are available for the same basalt, we have made "best-age" estimates (Table 2) based either on Sm-Nd ages, where only $\mathrm{Sm}-\mathrm{Nd}$ and $\mathrm{Rb}-\mathrm{Sr}$ ages have been determined, or on weighted averages of any combinations of the three different techniques. In addition, we have assigned a chemical classification to each dated rock where possible. This is greatly facilitated by the use of $\mathrm{Rb}$ and $\mathrm{Sr}$ concentrations determined by isotope dilution on whole rocks dated by the internal $\mathrm{Rb}-\mathrm{Sr}$ isochron technique (Fig. 5). Although chemical classification of Apollo 17 mare basalts is based on a larger number of elemental characteristics (RHODES et al., 1976; WARNER et al., 1979; NEAL et al., 1990a), accurate Rb concentrations are particularly diagnostic of each geochemical group, showing progressive enrichment from Type B1/B2, to Type A and, finally, Type $C$ basalts. Previously dated Type B basalts cannot be classified as Types $\mathrm{B} 1$ or $\mathrm{B} 2$ without additional REE data; however, we suspect that both magma types are represented in the present data set. Out of the 15 dated basalts, 6 are classified as Type A, 5 as Type B1/B2, and 2 as Type C (Fig. 4). Two remain undefined due to lack of geochemical data.

The weighted average age for all 28 dates from the 15 basalts is $3.72 \mathrm{Ga} \pm 0.04 \mathrm{Ga}$ (external population error of $0.13 \mathrm{Ga}$ ). 


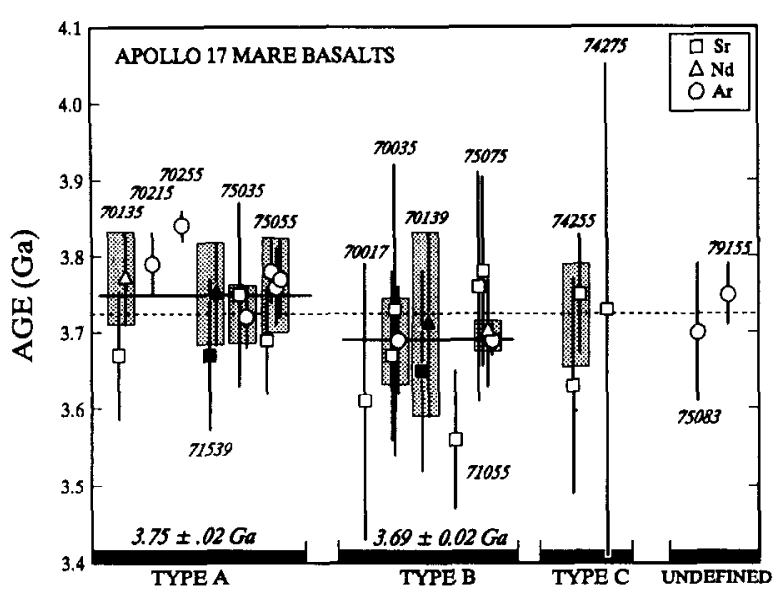

FIG. 4. Compilation of present (solid symbols) and published (open symbols) ages available for Apollo 17 high-Ti mare basalts (data and sources listed in Table 2). Symbol shape denotes the type of age determination: squares for $\mathrm{Rb}-\mathrm{Sr}$ isochrons; triangles for $\mathrm{Sm}-\mathrm{Nd}$ isochrons; and circles for ${ }^{40} \mathrm{Ar}-{ }^{39} \mathrm{Ar}$ techniques. Shaded boxes represent limits for "best-estimate" ages listed in Table 2. Dashed line represents the weighted average age of $3.72 \pm 0.04$ for all data. Basalts are also groupcd by geochemical type and yicld weighted average ages (solid horizontal lines) of $3.75 \pm 0.02 \mathrm{Ga}$ for Type $\mathrm{A}$ basalts and 3.69 $\pm 0.02 \mathrm{Ga}$ for Type B basalts. See text for discussion.

If only the "best-age" estimates from samples with multiple age determinations are considered, a better-defined weighted average age of $3.72 \pm 0.01 \mathrm{Ga}$ is obtained. This age is interpreted to represent the current best estimate of the average age of Apollo 17 high-Ti mare basalt volcanism. However, Type A basalts show a noticeable tendency towards slightly older ages relative to Type B1/B2 basalts (Fig. 4). Averaged separately using only the "best-age" estimates, Type A basalts yield a weighted mean age of $3.75 \pm 0.02 \mathrm{Ga}$ while Type $\mathrm{B} 1 / \mathrm{B} 2$ basalts yield a weighted mean age of $3.69 \pm 0.02 \mathrm{Ga}$. The low uncertainties associated with these weighted averages allow the $60 \mathrm{Ma}$ age difference between the two groups to be clearly resolved at the $95 \%$ confidence level. Further student- $t$ testing of the seven Type A and B1/B2 "best-age" estimates (five degrees of freedom) indicates that the two populations are distinct at the $99 \%$ confidence level. Ages for Type $\mathrm{C}$ basalts are represented by three $\mathrm{Rb}-\mathrm{Sr}$ dates from two rocks, and only one of these, 74255 , is known with reasonable certainty. Ages of $3.72 \pm 0.07 \mathrm{Ga}$ for 74255 and 3.73 $\pm 0.32 \mathrm{Ga}$ for 74275 (Table 2) are intermediate between average ages for Types A and B1/B2 volcanism. Previously reported ages for these rocks used the $1.39 \times 10^{-11} \mathrm{yr}^{-1}{ }^{87} \mathrm{Rb}$ decay constant, resulting in ages up to $3.83 \mathrm{Ga}$ (NYQUIST et al., 1976); however, no independent geochronometer has been applied to these samples. Additional dating using Sm-Nd and/ or ${ }^{40} \mathrm{Ar}-{ }^{39} \mathrm{Ar}$ chronometers is required before Type $\mathrm{C}$ basalts can be placed within the relative stratigraphy of Apollo 17 volcanism.

Presently available data suggest that duration of Apollo 17 high-Ti mare basalt volcanism lasted at least $50 \mathrm{Ma}$, but probably less than $200 \mathrm{Ma}$. We propose that age differences are correlatable to geochemical magma type, and that early magmatism was dominated by the eruption of Types A basalts while later activity was dominated by effusion of Type B1/
B2 basalts. The compositional transition may have occurred as two (or more) discrete pulses of magmatic activity separated by a significant hiatus, or activity may have taken place over a continuous, extracted episode with compositional changes occurring gradually throughout the stratigraphic interval. The inability to discriminate between $\mathrm{B} 1$ and $\mathrm{B} 2$ magmas provides an additional geochronological uncertainty given the complicated petrologic relationships between, as well as within, these two basalt groups. Further dating of well-analyzed samples may show that these two groups do not have a common age. However, present data are sufficient to indicate that, at least, Type B1 (and presumably B2 as well) basaltic activity was resolvably younger than that which produced most of the Type A basalts. The proposed chronology of earlier Types A magmas and later Type B1/B2 magmas is consistent with the relative abundances of heat-producing incompatible elements observed in the different lava types (RHODES et al., 1976; WARNER et al., 1979; NEAL et al., 1990a), particularly the radioactive alkali elements, $\mathrm{K}$ and $\mathrm{Rb}$. Whole-rock isotopic data, presented in the next section, indicate that these compositional differences do not arise from fractionation processes alone and that these patterns were inherited from heterogeneous mantle sources.

\section{WHOLE-ROCK ISOTOPIC DATA}

\section{Isotopic Compositions}

Fifteen whole-rock samples were chosen to best represent the geochemical variability observed within each geochemical group (Fig. 1). Results of Sr and Nd isotopic analyses (Table 3) are comparable with previously reported data on Apollo 17 high-Ti basalt (NYQUIST et al., 1974, 1975, 1976, 1979; LUGMAIR et al., 1975; UNRUH et al., 1984). Initial isotopic compositions calculated at the estimated eruptive ages exhibit only a limited range of $\mathrm{I}(\mathrm{Sr})$ variation within Types $\mathrm{A}$ $(0.699235$ to 0.699240$)$ and $C(0.699274$ to 0.699301$)$ groups, but a much broader range of $\mathrm{I}(\mathrm{Sr})$ for Types $\mathrm{B} 1$ and $\mathrm{B} 2$ basalts (0.699140 to 0.699239$)$. Types A, B1, and C basalts also show limited $\epsilon_{\mathrm{Nd}}$ variation $(+6.3$ to +7.2$)$ which is further reduced if all samples are calculated at the same age $(+6.5$ to +6.9 at $T=3.72 \mathrm{Ga})$. As with $\mathrm{I}(\mathrm{Sr})$, initial $\epsilon_{\mathrm{Nd}}$ in Type B2 lavas exhibit a much wider range of values from as low as +2.7 up to +6.0 . Given the good agreement of replicate analyses on 70139, along with the narrow range of initial $\mathrm{Nd}$ isotopic compositions in Types $\mathrm{A}, \mathrm{B} 1$, and $\mathrm{C}$ basalts, the wide range of initial $\epsilon_{\mathrm{Nd}}$ values observed in Type B2 samples (which were classified previously on the basis of their trace-element compositions; NEAL et al., 1990) is not considered to be an analytical artifact nor the result of preferential neutron bombardment on $\mathrm{B} 2$ samples alone. The wider ranges of initial $\mathrm{Sr}$ and $\mathrm{Nd}$ isotopic compositions observed in Type B2 basalts are interpreted to represent a fundamental difference between these and the Types A, B1, and C basalts. Model ages for all samples, based on the best estimated lunar initial $\mathrm{Sr}$ composition ( $\mathrm{T}_{\mathrm{LUNI}}$; NYQUIST et al., 1974b) and chondrite uniform reservoir ( $T_{\text {CHUR }}$; DEPAOLO and WASSERBURG, 1976), approximate or exceed the age of the Moon (Table 3), indicating multi-stage evolution of $\mathrm{Rb}-\mathrm{Sr}$ and $\mathrm{Sm}-\mathrm{Nd}$ within the basalt source regions. 


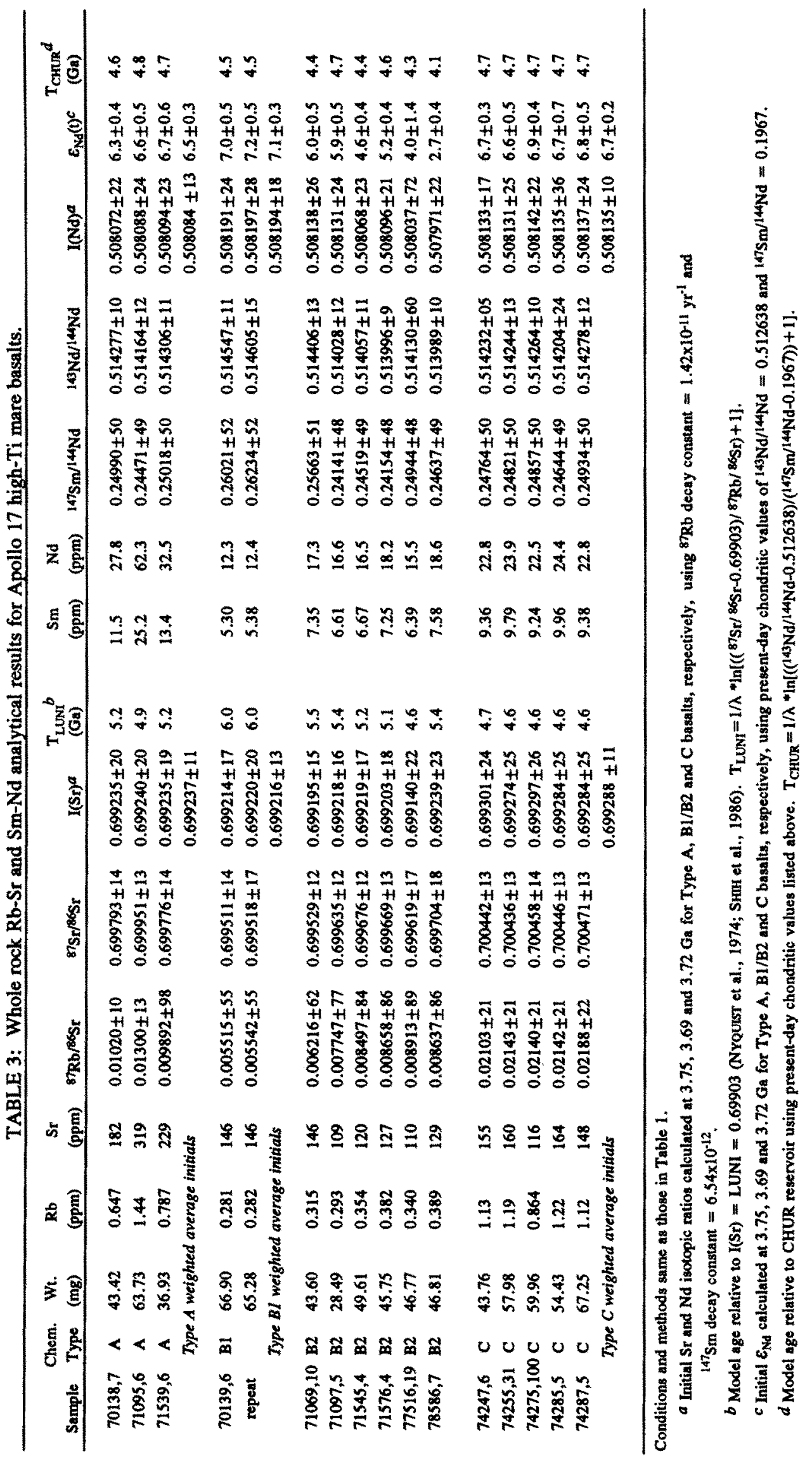




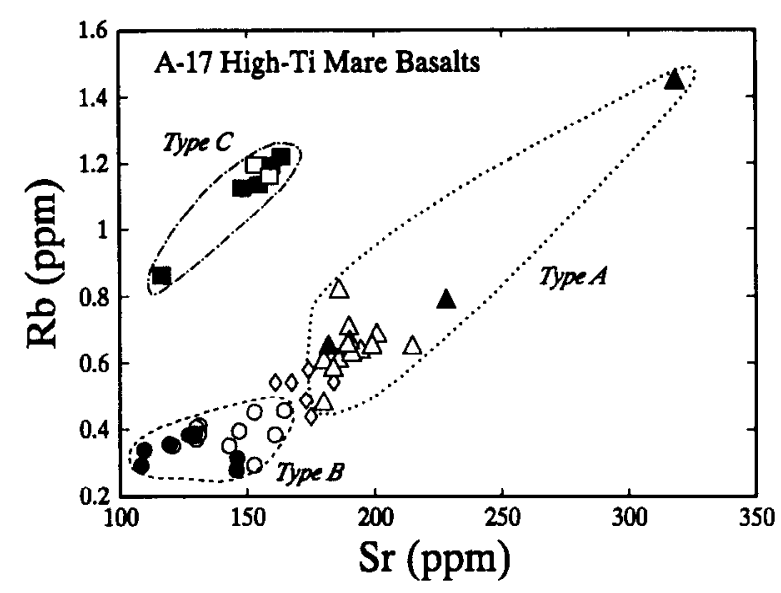

FIG. 5. Whole-rock concentration data determined by isotope dilution techniques for Apollo 17 mare basalts dated by the $\mathrm{Rb}-\mathrm{Sr}$ method. Filled symbols represent data obtained in the present study; open symbols represent data from previous studies (see Table 2 for sources). Triangles represent rocks classified as Type A basalts, circles as undifferentiated Type B basalts (B1 and B2), and squares as Type $\mathrm{C}$ basalts. Open diamonds represent lavas with $\mathrm{Rb}-\mathrm{Sr}$ compositions intermediate between Types $\mathbf{A}$ and $\mathbf{B}$.

Variations in initial isotopic compositions between geochemical groups cannot be solely explained by differences in the eruptive ages proposed abovc. On a plot of initial $\epsilon_{\mathrm{Nd}}$ versus $\mathrm{I}(\mathrm{Sr}$ ) (Fig. 6), Types $\mathrm{A}$ and $\mathrm{C}$ basalts form tight clusters with non-distinguishable initial $\epsilon_{\mathrm{Nd}}$ values, but with distinct I(Sr) ratios. The unique $\mathrm{Sr}-\mathrm{Nd}$ isotopic characteristics for these two groups are particularly well-defined if the weighted average initial compositions and resulting uncertainties are compared (Table 3, and shaded error boxes in Fig. 6). Although the field for Type B1 basalts is presently defined by only two analyses of sample 70139, it is largely resolved from the fields for Type $A$ and $C$ basalts. Some overlap between the Type A and B1 fields might be expected if additional analyses show excessive scatter. However, present data from Types A, Bl, and C basalts indicate that combined initial $\mathrm{Sr}$ $\mathrm{Nd}$ isotopic compositions for these three groups were unique, exhibiting a relatively restricted range in initial $\epsilon_{\mathrm{Nd}}$ with a somewhat larger range in $\mathrm{I}(\mathrm{Sr})$. Differences in initial $\epsilon_{\mathrm{Nd}}$ between these three groups are strongly dependent on the choice of eruptive ages used in the calculation; however, $\mathrm{I}(\mathrm{Sr})$ variations remain distinct regardless of the range of Apollo 17 mare basalt ages. This point is illustrated in Fig. 6 which also includes $\epsilon_{\mathrm{Nd}}$ and $\mathrm{I}(\mathrm{Sr})$ compositions for Types A and B1 basalts calculated at average age of Apollo 17 volcanism (i.e., 3.72 $\mathrm{Ga}$; open triangles and small circles, respectively). Although $\epsilon_{\mathrm{Nd}}$ compositions become indistinguishable at this age, differences in I(Sr) compositions between the three groups become slightly better resolved.

Initial isotopic compositions for Type B2 basalts are clearly resolvable from the weighted average compositions for Types A, B1, and C lavas. Type B2 lavas show a wide variation in initial isotopic compositions which is well outside of analytical uncertainties (large open circles, Fig. 6). The greatest variations are observed in initial $\epsilon_{\mathrm{Nd}}$ values which are all lower than that observed in 70139; however, $\mathrm{I}(\mathrm{Sr})$ compositions trend towards both higher and lower values relative to 70139 .
These isotopic differences might be used as criteria to further discriminate between Types B1 and B2 basalts. Although early work recognized that Type B basalts formed a continuum on many chemical variation diagrams (WARNER et al., 1975, 1979; RHODES et al., 1976), NEAL et al. (1990a) found that these basalts formed two sub-groups on the basis of REE ratios. Both 70139 and 71069 were previously classified as Type B1 basalts according to the elemental criteria outlined by NEAL et al. (1990a) and plot at either end of their B1 field (Fig. 1). However, the initial isotopic compositions of 71069 are outside of 70139 analytical errors and are more characteristic of the other Type B2 lavas. Although differences in isotopic compositions between these two basalts may be attributable to incorrectly assuming a common age for both rocks, this explanation cannot account for the scatter observed in other B2 basalts (see explanation of dashed lines in Fig. 6). Additionally, the $\mathrm{La} / \mathrm{Sm}$ ratio for 71069 is lower than the values observed for the relatively smooth, sub-horizontal trend defined by 70139 and the Types $A$ and $C$ lavas (heavy dashed line, Fig. 1). Isotopic data imply that 71069 has more affinities with other Type $B 2$ basalts and suggest that it may represent a continuation of the steeply sloping trend of $\mathrm{La} /$ Sm versus La defined by Type B 2 samples containing higher $\mathrm{La} / \mathrm{Sm}$. These data indicate that the discrimination between relatively unevolved Types B1 and B2 basalts with low La/ Sm may be difficult on the basis of trace-element chemical data alone.

\section{Whole-Rock Isochrons}

Types A, B1, and C whole-rock compositions form welldefined linear arrays on $\mathrm{Sr}$ and $\mathrm{Nd}$ isochron plots (Fig. 7) in spite of the observations that each group exhibits distinct isotopic characteristics. These arrays cannot be caused by

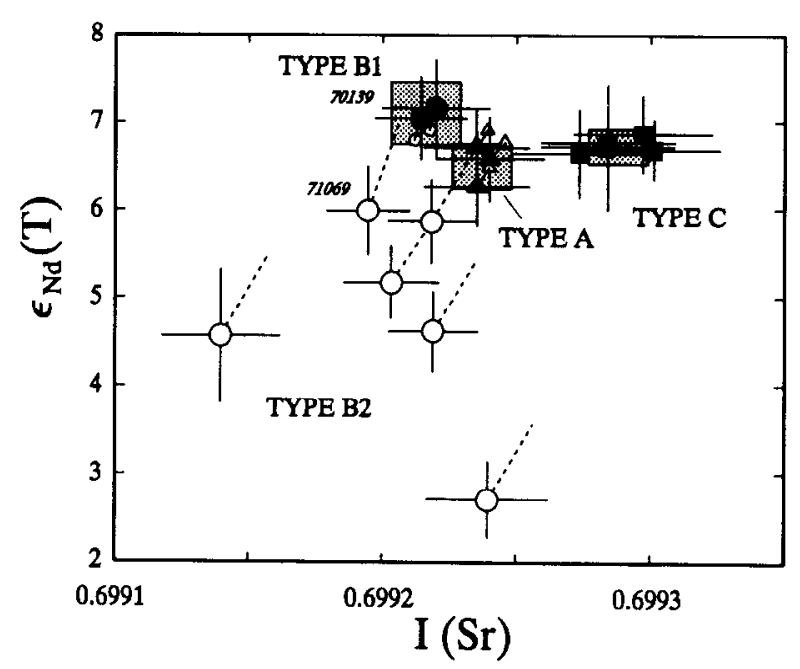

FIG. 6. $\epsilon_{\mathrm{Nd}}$ versus I(Sr) calculated at the estimated age of eruption for Types A (3.75 Ga; filled triangles), B ( $3.69 \mathrm{Ga}$; filled circles, Type B1; open circles, Type B2) and C (3.72 Ga; filled squares) basalts. Shaded boxes represent error limits of weighted averages for each group. Also shown are the initial ratios for Types A and B basalts calculated at the average age of Apollo 17 volcanism for comparison (3.72 Ga; small open triangles and circles, respectively, with tie-lines), and the effects of age correction if B2 samples are younger than the BI basalt analyzed (dashed lines calculated from 3.69 to $3.56 \mathrm{Ga}$ ). 
simple, two-component mixing since consistent linear trends are not observed on other bivariate elemental plots (e.g., nonlinear Rb-Sr arrays in Fig. 5). In addition, consistent twocomponent endmembers cannot be defined on the basis of major- and trace-element concentrations; for instance, Type $C$ basalts have $L a$ and $S r$ contents intermediate between Types $\mathrm{A}$ and $\mathrm{Bl}$, but have the highest $\mathrm{Rb}, \mathrm{MgO}$, and $\mathrm{Cr}$ contents (NEAL et al., 1990h). Since mixing cannot explain the welldefined linear arrays of whole-rock isotopic data, they should be assessed as isochrons which may preserve time significance. Type B2 analyses show excessive scatter in Fig. 7, particularly on the Sm-Nd isochron plot where two samples plot completely off of the diagram. The wide range of initial isotopic ratios calculated for Type $B 2$ basalts indicates that they no longer (if ever) satisfy the requirement for closed-system evolution from a common initial composition. Therefore, they are not included with the Types $\mathrm{A}, \mathrm{B} 1$, and $\mathrm{C}$ regressions. The resulting $\mathrm{Rb}-\mathrm{Sr}$ whole-rock regression, including two $\mathrm{B} 1$, three $A$, and five $C$ analyses, yields an age of $4.02 \pm 0.05 \mathrm{Ga}$ $\left(\lambda^{87} \mathrm{Rb}=1.42 \times 10^{-11} \mathrm{yr}^{-1}\right)$. This $\mathrm{Rb}-\mathrm{Sr}$ age is much more precise than internal isochrons determined from individual rocks, even though the range of ${ }^{87} \mathrm{Rb} /{ }^{86} \mathrm{Sr}$ for the whole rocks is substantially reduced. The higher precision is, in part, the statistical result of regressing a larger number of samples, but
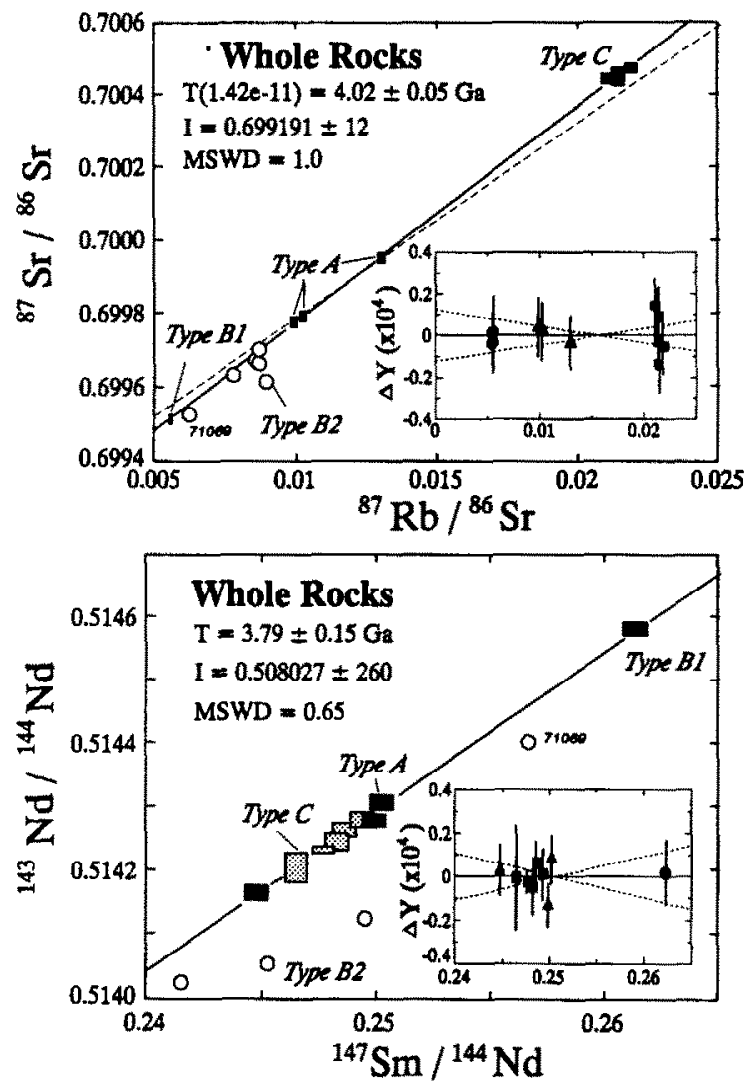

FIG. 7. Rb-Sr and Sm-Nd isochron plots for whole-rock data listed in Table 3 ( $\mathrm{Sr}$ isochron age $=4.11 \mathrm{Ga}$ using $\lambda^{87} \mathrm{Rb}=1.39 \times 10^{-11}$ $\mathrm{yr}^{-1}$ ). Data from Type B2 basalts (open circles) scatter off of the linear arrays defined by Types $\mathrm{A}, \mathrm{Bl}$, and $\mathrm{C}$ basalts and are not included in the regression analysis. Light dashed line in (a) represents mineral isochron for Type A basalt, 71539. Details listed for Fig. 2 apply equally to Fig. 7 . can also be attributed to the higher analytical precision of whole-rock determinations and a smaller amount of scatter of individual analyses about the best-fit curve. The cluster of five, isotopically similar Type $\mathrm{C}$ analyses heavily weighs the upper end of the line, strongly influencing the resulting age and, potentially, the associated uncertainty. In order to assess this control, weighted averages of the present-day ${ }^{87} \mathrm{Rb} /{ }^{86} \mathrm{Sr}$ and ${ }^{87} \mathrm{Sr} /{ }^{86} \mathrm{Sr}$ values could be calculated; however, this would introduce additional uncertainties in the averaged values caused by small, but real, variations in the $\mathrm{Rb} / \mathrm{Sr}$ introduced in the different samples at the time of crystallization. Instead, measured values of samples which most closely represent the average composition are regressed and result in ages of 4.01 $\pm 0.08 \mathrm{Ga}$ if only 74285 is used, and $4.03 \pm 0.07 \mathrm{Ga}$ if both 74285 and 74287 are used. These age uncertainties are slightly larger than the $0.05 \mathrm{Ga}$ value calculated for all ten analyses, but are still remarkably precise given the small range in $\mathrm{Rb}$ / $\mathrm{Sr}$ in these rocks. The low age uncertainties for these regressions indicate that the $4.02 \mathrm{Ga}$ whole-rock $\mathrm{Rb}-\mathrm{Sr}$ age does not represent a "two-point" isochron and also suggest that although individual mineral phases (particularly, any adhering mesostasis) may have been subjected to slight disruption of the $\mathrm{Rb}-\mathrm{Sr}$ system, whole rocks remained closed to $\mathrm{Rb}$ or Sr flux on the scale of basalt fragment sizes $(200-750 \mathrm{mg})$. Ironically, the more-precise $\mathrm{Rb}-\mathrm{Sr}$ whole-rock isochron age is 270 to $330 \mathrm{Ma}$ older than the eruptive age of the basalts. In contrast, the less-precise Sm-Nd whole-rock isochron age of $3.79 \pm 0.15 \mathrm{Ga}$ is nearly identical to the eruptive age of the Type A magmas, and within error of the enuptive age of the Type B1/B2 basalts. The validity of the whole-rock isochron ages and their implications on models of cumulate source heterogeneity are discussed in the next section.

\section{DISCUSSION}

\section{Open-System Evolution vs. Source Heterogeneity}

Isotopic data presented earlier support the classification of Apollo 17 high-Ti mare basalts into previously defined geochemical groups. The unique isotopic characteristics of each geochemical basalt-type could not have been acquired from a common mantle source through closed-system magmatic processes (i.e., partial melting and fractional crystallization). However, post-melting, open-system processes, such as fractionation combined with assimilation of KREEP or lunar crust (SHIH et al, 1986; NEAL et al., 1989), are capable of modifying isotopic compositions and must be investigated as a potential cause for the observed isotopic variations.

Type A magmas show very little isotopic variation over a large range of $\mathrm{Sr}$ and $\mathrm{Nd}$ concentrations (Fig. 8). The absence of plagioclase as a microphenocryst phase, as well as observed $\mathrm{CaO}, \mathrm{Al}_{2} \mathrm{O}_{3}$, and Eu abundances and $\mathrm{CaO} / \mathrm{Al}_{2} \mathrm{O}_{3}$ ratios, indicate that plagioclase was not a major fractionating phase during petrogenesis of any of the Apollo 17 high-Ti magmas (WARNER et al., 1975, 1979; RHODES et al., 1976; NEAL et al., 1990a). Consequently, observed $\mathrm{Sr}$ and $\mathrm{Nd}$ isotopic and concentration data are compatible with a closed-system, nearsurface fractionation model where the remaining liquid would become progressively enriched in both of these incompatible elements while isotopic compositions remained constant. The 

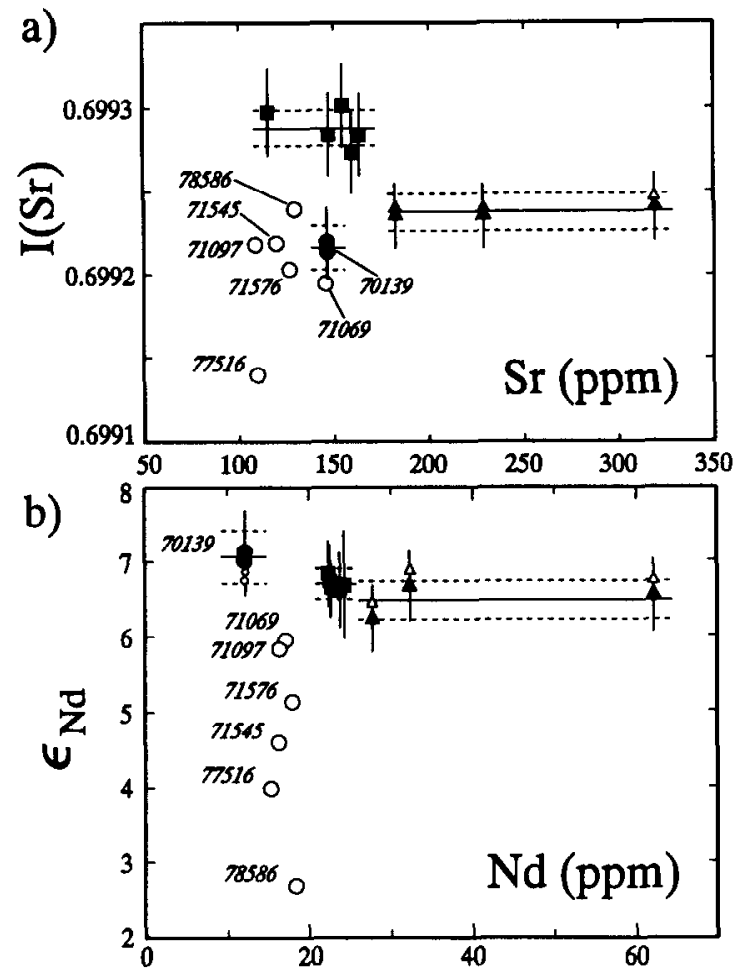

FiG. 8. Initial isotope ratio (calculated at their age of eruption) versus element plots for whole-rock data listed in Table 3. Same symbols as in Fig. 6 . Also shown are weighted average isotopic compositions (solid horizontal lines) and $95 \%$ confidence limits (dashed lines) for Types A, B1, and C basalts.

observation that both 70138 and 71095 whole-rock analyses fall on 71539 internal $\mathrm{Sr}$ and $\mathrm{Nd}$ isochrons (Fig. 3) lends strong support to closed-system evolution of Type A magmas. NEAL et al. (1990a) were able to apply closed-system, Rayleigh fractionation models to Type A basalts which require 40$80 \%$ crystallization of a hypothetical mafic parent to produce the range of observed derivative-magma compositions. In addition, the most-evolved Type $A$ basalt analyzed in this study (71095) was noted as the only example of a Type II, Apollo 11 low-K type high-Ti basalt recognized in the Apollo 17 suite (NEAL et al., 1990a). The nearly identical initial isotopic composition of this and the other two Type A basalts implies a direct genetic link to a common parental magma through extreme amounts of fractionation.

Unlike Type A magmas, Type C magmas show a tight clustering of $\mathrm{Sr}$ and $\mathrm{Nd}$ concentrations, as well as isotopic compositions (Fig. 8). Other elemental abundances show equally limited ranges within the recognized Type $\mathrm{C}$ suite (NEAL et al., 1990b). Type C basalts are exceedingly rare (five of six known samples are analyzed in this study) and their areal distribution appears to be limited to the immediate vicinity of Shorty Crater (RHODES et al., 1976; WARNER et al., 1979; NEAL et al., 1990b). Although they contain higher $\mathrm{MgO}$ and $\mathrm{Cr}$ abundances than Types $\mathrm{A}$ and $\mathrm{B}$ basalts. Type $\mathrm{C}$ basalts are most notable in their enrichment of $\mathrm{Rb}$ (Fig. 4; RHODES et al., 1976; WARNER et al., 1979; NEAL et al., 1990b). The limited ranges of geochemical and isotopic compositions, along with their scarcity, suggest that all Type $C$ samples may have been derived from a single batch of magma, and possibly even a single lava flow. The petrogenesis of Type $C$ basalts is discussed in greater detail by NEAL et al. (1990b).

In contrast to Types $A$ and $C$ basalts which show no intragroup isotopic variability, Type B2 magmas exhibit a large range in initial isotopic compositions over only small ranges in $\mathrm{Sr}$ and $\mathrm{Nd}$ concentrations (Fig. 8). Type B2 samples form a distinct, near-vertical trend on a plot of $\epsilon_{\mathrm{Nd}}$ versus Nd (Fig. $8 \mathrm{~b})$. A similar array is not observed when $\mathrm{I}(\mathrm{Sr})$ is plotted against $\mathrm{Sr}$; instead, Type B2 samples form a diffuse cluster (Fig. 8a). Although Type B1 70139 plots at the high $\epsilon_{\text {Nd }}$-low $\mathrm{Nd}$ end of the array in Fig. $8 \mathrm{~b}$, there is no obvious $\mathrm{I}(\mathrm{Sr})$ relationship between Types B1 and B2 magmas in Fig. 8a. In addition to their variable initial ratios, Type $\mathrm{B} 2$ magmas commonly do not fall on whole-rock isochrons defined by Types A, B1, and C magmas (Fig. 7). We interpret the isotopic data as evidence that the Type $B 2$ magmas experienced postmelting, open-system evolution. This conclusion differs from the one recently proposed by NEAL et al. (1990a) who utilized geochemical modelling to demonstrate, on the basis of major and trace elements alone, that Type B2 compositional variations can be adequately explained by closed-system fractionation from a distinct parent magma with elevated La/ $\mathrm{Sm}$. Isotopic data presented here argue strongly for a model requiring assimilation of additional contaminants during evolution of Type B2 magmas. In spite of the single trend of $\epsilon_{\mathrm{Nd}}$ vs. Nd, Type B2 compositional variations cannot be explained through simple, two-component AFC processes using KREEP, or any single crustal component as the assimilant. The pattern and sequence of $\epsilon_{\mathrm{Nd}}$ depletion observed for Type B2 samples in Fig. 8 b is not duplicated on the $\mathrm{Sr}-\mathrm{Nd}$ isotope plot (Fig. 6), nor on other isotope-element or element-element diagrams. Modelling of AFC processes is also complicated by the difficulty in choosing an appropriate uncontaminated parent magma. While the least-evolved (i.e., highest $\mathrm{MgO}$, $\mathrm{Cr}_{2} \mathrm{O}_{3}, \mathrm{Sm} / \mathrm{Nd}$, lowest La, $\mathrm{Hf}, \mathrm{Rb} / \mathrm{Sr}$ ) Type $\mathrm{B} 1$ magma, 70139, cannot be ruled out, its $\mathrm{I}(\mathrm{Sr})$ and $\mathrm{La} / \mathrm{Sm}$ are intermediate within the range of Type B2 compositions. Given the limited number of analyses in the present study and the uncertainty in assuming a common age for both Types B1 and B2, a detailed examination of Type B2 petrogenesis is not possible at present. However, we suspect that these magmas experienced a complex magmatic history involving several different assimilants, parent magmas, or even source regions in order to explain observed compositions.

In summary, whole-rock isotopic data suggests that the Type B2 basalts were the only Apollo 17 high-Ti magmas which suffered extensive interaction with lunar crust. Type A basalts exhibit the most convincing isotopic evidence in support of closed-system magmatic evolution. Their large range in geochemical compositions requires the presence of at least several flows which presumably evolved in magma chambers at some depth within the lunar crust. It is unlikely that these basalts could have acquired their highly evolved geochemical compositions while maintaining their uniform initial isotopic signatures if they suffered any concurrent crustal assimilation. Therefore, Type A isotopic compositions are inferred to have been inherited from their mantle source region. Although similar strong evidence is lacking for Types $\mathrm{C}$ and $\mathrm{B} 1$ magmas, we assume that neither of these two geo- 

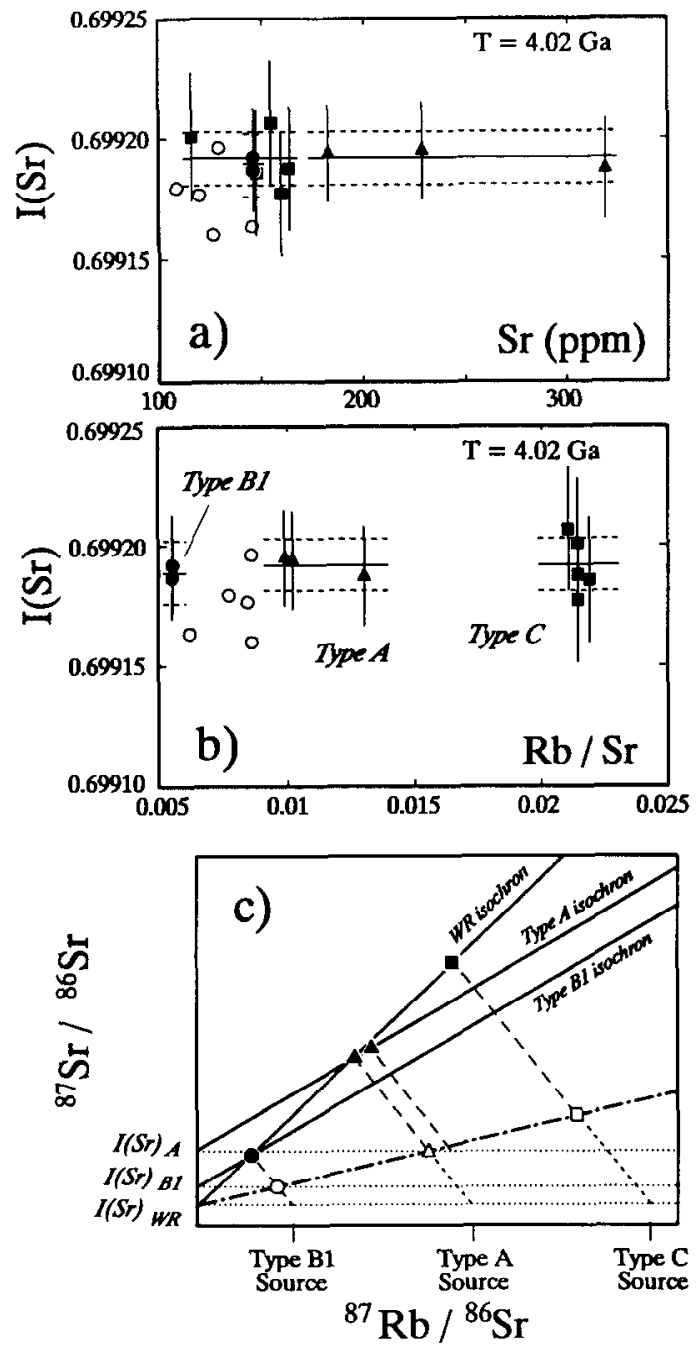

FIG. 9. "Initial" ${ }^{87} \mathrm{Sr} /{ }^{86} \mathrm{Sr}$ ratios for Types $\mathrm{A}, \mathrm{B} 1$, and $\mathrm{C}$ source regions calculated at $4.02 \mathrm{Ga}$ plotted against (a) Sr concentration and (b) $\mathrm{Rb} / \mathrm{Sr}$ ratios measured in whole rocks. Also shown are the weighted average initial compositions and error limits for Types A, B1, and C basalts which are essentially identical. (c) Schematic diagram illustrating the growth of ${ }^{87} \mathrm{Sr}{ }^{86} \mathrm{Sr}$ with time in whole rocks. At $4.02 \mathrm{Ga}$, all three sources have a common $\mathrm{I}(\mathrm{Sr})_{\mathrm{WR}}$, but a range of recently modified ${ }^{87} \mathrm{Rb} /{ }^{86} \mathrm{Sr}$ ratios. At around $3.7 \mathrm{Ga}$ (dash-dot isochron), basalts are generated and preserve the ${ }^{87} \mathrm{Rb} /{ }^{86} \mathrm{Sr}$ and initial ratios inherent in their respective source regions (open symbols and dotted lines at $\mathrm{I}(\mathrm{Sr})_{B}$ and $\left.\mathrm{I}(\mathrm{Sr})_{A}\right)$. Minor $\mathrm{Rb} / \mathrm{Sr}$ fractionation during melting, or very high degrees of crystallization, or magma mixing, may cause some increases in ${ }^{87} \mathrm{Rb} /{ }^{86} \mathrm{Sr}$ (e.g., two values for Type A). Present-day basalt compositions are shown as solid symbols and lie both on parallel $3.7 \mathrm{Ga}$ mineral isochrons and on the steeper $4.0 \mathrm{Ga}$ whole-rock isochron (solid, bold lines). Note similarities to Type A and wholc-rock isochrons shown in Fig. $7 \mathrm{a}$.

chemical groups experienced significant crustal assimilation. This assumption is supported by the fact that neither magma type exhibits the intra-group isotopic variability observed in Type $\mathrm{B} 2$ magmas and, more importantly, by the fact that data for both Types C and B1 plot on the whole-rock Nd isochron defined by Type A basalts alone. The resulting age of $3.79 \mathrm{Ga}$ for the $\mathrm{Nd}$ whole-rock isochron (nearly identical to the age of eruption of Type A basalts) and the discordance of contaminated Type $\mathrm{B} 2$ magmas provide additional support for assuming that Types A, B1, and C evolved under closedsystem conditions. In addition, differences in initial isotopic compositions between these three groups indicate that Types $A, B 1$, and C parent magmas were distinct and that primary magmas for each geochemical group were derived from isotopically unique mantle sources. Thus, isotopic data presented in this paper support previous petrogenetic interpretations based on major- and trace-element geochemistry which involved relatively simple fractionation of observed microphenocryst phases from compositionally distinct source regions (NEAL et al., 1990a). Isotopic evidence suggesting that B2 melts were modified by crustal contamination eliminates much of the need for. previously proposed models (SHIH et al., 1975; WARNER et al., 1979) requiring differing degrees of partial melting in order to explain observed compositional variations (e.g., $\mathrm{La} / \mathrm{Sm}$ ratios).

\section{Origin of Source Heterogeneities}

Whole-rock isotopic data for Types A, B1, and C basalts present an apparent conflict between the $\mathrm{Sr}$ and $\mathrm{Nd}$ systems. On the one hand, variations in initial $\mathrm{Nd}$ isotopic data are largely a result of the time-integrated effects of the similar $\mathrm{Sm} / \mathrm{Nd}$ ratios calculated at different eruptive ages. Variations in ${ }^{147} \mathrm{Sm} /{ }^{144} \mathrm{Nd}$ ratios between the three different groups is only about $5 \%$, and the Nd whole-rock isochron (Fig. 7b) yields an age almost identical to the average eruptive age. These observations suggest that source regions for each group contained only minor differences in REE distributions and $\mathrm{Nd}$ isotopic compositions.

On the other hand, Sr data indicate that each mantle source is isotopically distinct. Age versus initial $\mathrm{Sr}$ composition error parallelograms for 70139 (Type B1) and 71539 (Type A) (Fig. $10 \mathrm{a})$, as well as non-overlaping $\mathrm{I}(\mathrm{Sr})$ errors for Type $\mathrm{C}$ basalts (Fig. 6), define unique source characteristics. Even though the different basalts record $\mathrm{Sr}$ isotopic heterogeneities in their respective sources, the $\mathrm{Sr}$ whole-rock data yield a well-defined, albeit anomalously old, age of $4.02 \pm 0.05 \mathrm{Ga}$. Taken at face value, this implies that all three Apollo 17 mare basalt sources had a homogeneous ${ }^{87} \mathrm{Sr} /{ }^{86} \mathrm{Sr}$ composition of 0.699191 \pm 0.000012 at $4.02 \mathrm{Ga}$. It is unlikely that this age represents the time at which mantle cumulates crystallized from a homogeneous magmasphere since it is some $400 \mathrm{Ma}$ younger than previous estimates of $4.4 \mathrm{Ga}$ (CARLSON and LUGMAIR, 1979; NYQUIST et al., 1979, 1981; TAYLOR, 1982) and would require anomalously slow rates of cooling of the magmasphere (TAYLOR, 1982).

The 4.02 Ga whole-rock $\mathrm{Rb}-\mathrm{Sr}$ isochron has age significance only if there has been no fractionation of $\mathrm{Rb}$ and $\mathrm{Sr}$ at the time of melt generation. NYQUIST et al. (1979) have convincingly argued that partial melts derived from a source containing clinopyroxene as a residual phase will contain $\mathrm{Rb} / \mathrm{Sr}$ ratios which are higher than that of the source due to the difference in $\mathrm{Rb}$ and $\mathrm{Sr}$ mineral/liquid partition coeffcients in Ca-rich pyroxene (0.015 for $\mathrm{Rb}$ and 0.116 for $\mathrm{Sr}$ : PhilpotTs and SCHNETZLER, 1970). Since the Rb/Sr fractionation which takes place during partial melting is much smaller than the fractionation which occurred during crystallization of magmasphere cumulates (due to extraction of 


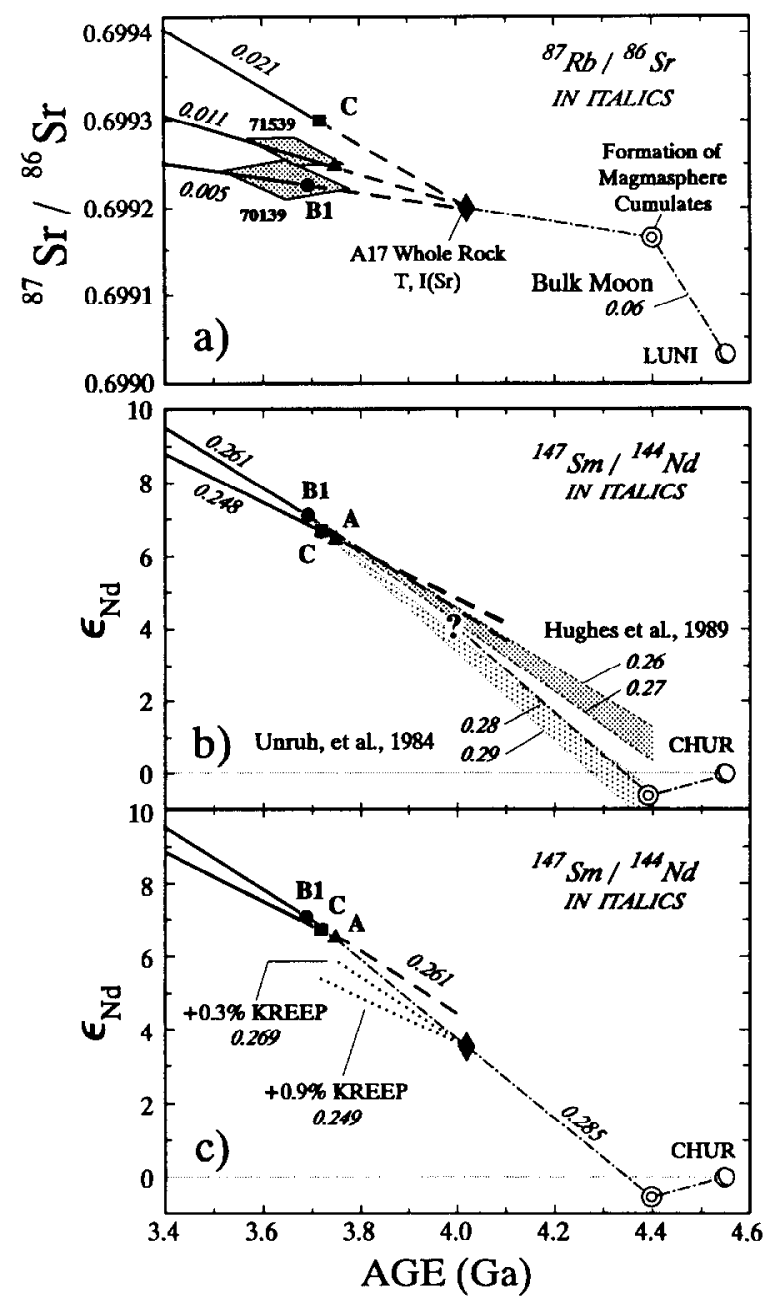

FIG. 10. Isotope evolution diagrams for average Types A, B1, and $\mathrm{C}$ mare basalts. Radiogenic growth is projected back to the estimated age of eruption (solid lines) using average present-day isotopic ratios and measured $\mathrm{Rb} / \mathrm{Sr}$ and $\mathrm{Sm} / \mathrm{Nd}$. Extensions of these same evolution paths to $4.02 \mathrm{Ga}$ (i.e., no fractionation of $\mathrm{Rb} / \mathrm{Sr}$ or $\mathrm{Sm} / \mathrm{Nd}$ at time of melting) are shown by dashed lines. Also shown are Sr error parallelograms for 71539 and 70139 from isochron determinations (large, stippled polygons), the age and $\mathrm{I}(\mathrm{Sr})$ composition of the $\mathrm{Rb}-\mathrm{Sr}$ wholerock isochron (filled diamond), and estimated evolution paths for the magmasphere (dash-dot line from LUNI/CHUR to formation of magmasphere cumulates at about $4.4 \mathrm{Ga}$ after previously-proposed models; NYQUIST et al., 1977, 1979, 1981; UNRUH et al., 1984). In (b) Nd isotopic compositions for the Type Bl source are modelled assuming that 70139 represents $10 \%$ (lower boundaries of stippled fields) and 15\% (upper boundaries) partial melts of original cumulates with modal compositions and mineral partition coefficients given by UNRI JH et al. (1984) and HuGHFS et al. (1989). Note that the ${ }^{147} \mathrm{Sm} /$ ${ }^{144} \mathrm{Nd}$ for both Type $\mathrm{A}$ and $\mathrm{C}$ are identical. In (c) dotted lines show the divergent evolutionary paths for Types $A$ and $C$ source regions assuming that small amounts of KREEP are mixed with original $B 1$ mantle cumulates at $4.0 \mathrm{Ga}$ (mixing model from Table 4).

a plagioclase crust), whole-rock ages should approximate the ages of formation of basalt sources (NYQUIST et al., 1979). However, these authors also argue that rigorous source-region time significance cannot be placed in whole-rock isochrons because of the melt-induced $\mathrm{Rb} / \mathrm{Sr}$ fractionation. Their earlier work with Apollo 17 basalts (NYQUIST et al., 1976) modelled 0.25 - to 5-fold increases in $\mathrm{Rb} / \mathrm{Sr}$ ratios between Type $\mathrm{B}$ to
Type $\mathrm{C}$ melts and their respective cumulate sources. These results were interpreted as evidence for a two-stage evolution for Apollo 17 cumulate sources involving crystallization at $4.4 \mathrm{Ga}$ of cumulate sources exhibiting a range in ${ }^{87} \mathrm{Sr} /{ }^{86} \mathrm{Sr}$ compositions followed by closed-system evolution until basaltic liquids were remelted between 3.7 and $3.8 \mathrm{Ga}$ (Fig. 5, NYQuisT et al., 1976).

Several lines of isotopic and petrologic evidence force us to reexamine the extent of $\mathrm{Rb} / \mathrm{Sr}$ fractionation that occurred during generation of Apollo 17 high-Ti melts. Most importantly, the high degree of precision of the $4.0 \mathrm{Ga}$ whole-rock isochron, relative to other whole-rock regressions, limits the amount of $\mathrm{Rb} / \mathrm{Sr}$ fractionation which could have occurred at the time of melting. As argued previously, this precision is not an artifact of a large spread in initial ${ }^{87} \mathrm{Rb} /{ }^{86} \mathrm{Sr}$ values nor of an uneven distribution of analyses (i.e., a two-point isochron). Parallel REE patterns between magma types (NEAL et al., 1990a,b) and relatively constant $\mathrm{La} / \mathrm{Sm}$ ratios (Fig. 1) indicate similar REE distributions between source regions and comparable degrees in partial melting. If the entire range in Apollo $17 \mathrm{Rb} / \mathrm{Sr}$ compositions was derived during partial melting by increasing these ratios in the melts relative to a homogeneous source, the $\mathrm{Sr}$ whole-rock isochron should yield an age close to the average age of Apollo 17 volcanism. However, if the sources contained a range of $\mathrm{Rb} / \mathrm{Sr}$ prior to melting, further melt-induced fractionation of $\mathrm{Rb}$ and $\mathrm{Sr}$ would only tend to disrupt the linearity of the whole-rock data and increase, rather than decrease, the scatter of points about the best-fit isochron regression. Alternatively, if the cumulate source regions inherited substantial ${ }^{87} \mathrm{Sr} /{ }^{86} \mathrm{Sr}$ heterogeneity at the time of magmasphere crystallization (e.g., Fig. 5, NYQUIST et al., 1976), the resulting melts should not be expected to form a well-defined isochron array at any time.

The small amount of scatter associated with the Sr wholerock isochron is also illustrated by initial $\mathrm{Sr}$ ratios calculated at $4.02 \mathrm{Ga}$ for individual Types $\mathrm{A}, \mathrm{B} 1$, and $\mathrm{C}$ whole rocks (Fig. 9a and b). Values for $\mathrm{I}(\mathrm{Sr}$ ) fall well within the limits of analytical error between 0.699206 and 0.699185 , while both $\mathrm{Sr}$ concentrations and $\mathrm{Rb} / \mathrm{Sr}$ ratios show much broader ranges. Weighted average $\mathrm{I}(\mathrm{Sr})$ calculated at $4.02 \mathrm{Ga}$ for all three magma types show a remarkably good agreement of $0.699189 \pm 0.000013$ for the two analyses of 70139 (Type B1) and $0.699192 \pm 0.000011$ for the three Type A and five Type $C$ basalts. These data suggest that the range in $\mathrm{Rb} / \mathrm{Sr}$ ratios was established at around $4.0 \mathrm{Ga}$ at a time when all three source regions had very homogeneous $\mathrm{Sr}$ isotopic compositions, and that the $\mathrm{Rb} / \mathrm{Sr}$ could not have been substantially modified during subsequent melt gencration or crystal fractionation without disturbing these relationships. Additionally, the very low values of ${ }^{87} \mathrm{Rb} /{ }^{86} \mathrm{Sr}$ in 70139 also support a melting model which does not allow fractionation of $\mathrm{Rb}$ from Sr. Strontium isotopic evolution paths for the three groups converge at 0.699191 at $4.0 \mathrm{Ga}$ using ${ }^{87} \mathrm{Rb} /{ }^{86} \mathrm{Sr}$ measured in the basalts (Fig. 10a). However, if the Type B1 path is projected further back in time using its measured ${ }^{87} \mathrm{Rb} /$ ${ }^{86} \mathrm{Sr}$, it coincidentally intersects the path of previously proposed models for the evolving Bulk Moon at the time of magmasphere crystallization around $4.4 \mathrm{Ga}$ (using LUNI $=0.69903$ and ${ }^{87} \mathrm{Rb} /{ }^{86} \mathrm{Sr}_{\text {BULK MOON }}=0.06$; NYQUIST et al., $1976,1977,1981)$. The internal consistency of our data with 
models derived from different data sets provides further evidence that 70139 (Type B1) most likely preserves the originally formed mantle cumulate ${ }^{87} \mathrm{Rb} /{ }^{86} \mathrm{Sr}$ ratio with little or no modification. Since REE data allow only subtle differences in the degree of melting between Types $B 1$ and $C$ liquids, it does not seem unreasonable that both Type B1 and Type $C$ (as well as Type A) melts would preserve their respective mantle-source $\mathrm{Rb} / \mathrm{Sr}$ ratios.

Finally, if the variations in ${ }^{87} \mathrm{Rb} /{ }^{86} \mathrm{Sr}$ ratios between basalt groups are the result of fractionation through varying degrees of partial melting, the magnitude of the $\mathrm{Rb} / \mathrm{Sr}$ increases should be well correlated with relative decreases in ${ }^{147} \mathrm{Sm} /$ ${ }^{144} \mathrm{Nd}$ between groups. Although the Type B1 basalt contains the lowest ${ }^{87} \mathrm{Rb} /{ }^{86} \mathrm{Sr}$ and highest ${ }^{147} \mathrm{Sm} /{ }^{144} \mathrm{Nd}$, Types $\mathrm{A}$ and $\mathrm{C}$ basalts have identical ${ }^{147} \mathrm{Sm} /{ }^{144} \mathrm{Nd}$ ratios (average values of 0.2483 and 0.2480 , respectively), but ${ }^{87} \mathrm{Rb} /{ }^{86} \mathrm{Sr}$ ratios which vary by a factor of $2(0.011$ versus 0.021 , respectively). These observations are inconsistent with accepted models of mineral/melt partitioning during progressive partial melting and indicate that enrichments in $\mathrm{Rb} / \mathrm{Sr}$ cannot be solely attributed to melt-related fractionation.

Isotopic evidence implying a minimal amount of $\mathrm{Rb} / \mathrm{Sr}$ fractionation during partial melting requires that late-crystallizing cumulus Ca-rich clinopyroxene (as well as any plagioclase) originally present within the source could not have been present as a major phase within the melt residue. Petrologic models based on experimental, major- and trace-element constraints (GREEN et al., 1975; KESSON, 1975; BINDER, 1985; HUGHES et al., 1989) suggest that high-Ti basalt sources are relatively shallow $(<400 \mathrm{~km})$ and are probably dominated by early-formed olivine cumulates. A range of cumulate modes and $F$ values (fraction of melt generated) have been postulated, most of which can be made compatible with a residue largely depleted in clinopyroxene. The hybridized source models of HuGHES et al. (1989) hypothesize that latestage clinopyroxene, ilmenite, and plagioclase cumulates, along with trapped liquid, are likely to have formed only a small proportion of the high-Ti basalt source regions $(<12 \%)$ and would have been completely consumed during cumulate remelting of between 10 and $15 \%$. This conclusion is also consistent with models based on Nd-Hf isotopic data which suggest clinopyroxene modal abundances of $8-18 \%$ in the Apollo 17 source and 3-15\% partial melting calculated to produce observed mare compositions (UNRUH et al., 1984). Although these melting models are highly assumption-dependent, we believe that they can be used to support the conclusion that most or all of the Ca-rich clinopyroxene present in the source regions for Apollo 17 high-Ti basalts was exhausted during partial melting, and that $\mathrm{Rb} / \mathrm{Sr}$ ratios measured in the basalts are not substantially modified from the values which were present within their mantle sources. This conclusion implies that the $4.02 \mathrm{Ga}$ whole-rock $\mathrm{Sr}$ age reported earlier has significance in the evolution of the sources of Apollo 17 mare basalts.

Present $\mathrm{Sr}$ isotopic data preserve evidence that the mantle source regions experienced a complex geochemical history during the period between solidification of source cumulates from the lunar magmasphere and generation of Apollo 17 mare basalts (Fig. 10a). These data are consistent with a model where an initial, isotopically homogeneous source region for Apollo 17 high-Ti basalts crystallized during the late stages of lunar magmasphere solidification around 4.4 Ga (HUGHES et al., 1989). This model also accommodates early lunar $\mathbf{S r}$ isotopic evolution based on previous estimates of the Bulk Moon ${ }^{87} \mathrm{Rb} /{ }^{86} \mathrm{Sr}$ and I(Sr) LUNI (NYQUIST et al., 1977, 1979, 1981). Crystallization of the magmasphere resulted in depletions in LREE and LIL elements within original mantle cumulates. The low ${ }^{87} \mathrm{Rb} /{ }^{86} \mathrm{Sr}$ ratio of about 0.005 in the initially homogeneous cumulates caused only very slow growth of radiogenic Sr (near horizontal dash-dot line, Fig. 10a). However, a geochemical event at around 4.0 Ga created a twoto four-fold increase in ${ }^{87} \mathrm{Rb} /{ }^{86} \mathrm{Sr}$ ratios within what would later become the Types $A$ and $C$ basalt sources, respectively, while leaving the Type B1 source unaffected. The new ${ }^{87} \mathrm{Rb} /$ ${ }^{86} \mathrm{Sr}$ ratios caused the $\mathrm{Sr}$ evolution paths for each source region to diverge such that resolvable differences in ${ }^{87} \mathrm{Sr} /{ }^{86} \mathrm{Sr}$ were developed by the time high-Ti magmas were generated at 3.7 Ga. This evolution is also depicted schematically on an isochron plot (Fig. 9c) illustrating the growth of ${ }^{87} \mathrm{Sr} /{ }^{86} \mathrm{Sr}$ (short dashed lines) within the three different sources from 4.0 to 3.8 (open symbols and dashed-dot isochron), and subsequent growth within the basalts (long dashed lines) to the present day (filled symbols and solid isochrons).

Unlike the more-ancient, $\mathrm{Sr}$ whole-rock isochron, $\mathrm{Nd}$ whole-rock data preserve an isochron age of $3.79 \pm 0.15 \mathrm{Ga}$ which is nearly identical to the eruptive age of the basalts. This suggests that either the REEs were not affected by the chemical processes which altered $\mathrm{Rb} / \mathrm{Sr}$ ratios in the mantle cumulates at $4.0 \mathrm{Ga}$, or that any REE modifications affected only absolute abundances without changing $\mathrm{Sm} / \mathrm{Nd}$ ratios in the different sources. Although some fractionation of $\mathrm{Sm}$ / Nd most likely occurred during generation of the high-Ti basalts (Fig. 10b), present Nd isotopic data place limits on $\mathrm{Sm} / \mathrm{Nd}$ ratios in the source regions. If magmasphere cumulates had a chondritic to slightly enriched $\epsilon_{\mathrm{Nd}}$ composition at $4.4 \mathrm{Ga}$ (NYQUIST et al., 1977, 1979; UNRUH et al., 1984), the ${ }^{147} \mathrm{Sm} /{ }^{144} \mathrm{Nd}$ of a single-stage source region just prior to melting must have been between 0.27 and 0.29 (Fig. 10c). These values are within the range calculated from the basalt melting models in Fig. 10b. If the Type B1 source remained unmodified since crystallization of magmasphere cumulates, as hypothesized from $\mathrm{Sr}$ isotopic data, its $\epsilon_{\mathrm{Nd}}$ evolution would be controlled by a ${ }^{147} \mathrm{Sm} /{ }^{144} \mathrm{Nd}$ ratio of around 0.286 . Types $A$ and $C$ magmas have $\epsilon_{\mathrm{Nd}}$ values which are nearly coincident with this path at the time of their eruption. This coincidence indicates that modification of Types $A$ and $C$ source regions at $4.0 \mathrm{Ga}$ by a process capable of imparting $\mathrm{Rb}$-enrichments could not have simultaneously introduced a LREE-enriched component. If it had, the time-integrated effects of the altered $\mathrm{Sm} / \mathrm{Nd}$ ratios in the different sources would have resulted in Types $\mathrm{A}$ and $\mathrm{C}$ magmas with lower $\epsilon_{\mathrm{Nd}}$ values than those observed (dotted lines, Fig. 10c). It may be possible that the absolute abundances of all REEs were modified sympathetically by some process leaving REE ratios in the resulting mantle sources unaffected. However this possibility seems unlikely given the wide range of REE patterns expected for processes involving melting, metasomatism, and/or mixing within the lunar mantle. The data presented here suggest that 
Tahle 4: Illustrative mixing model between high-Ti mare basalt source and KREEP components.

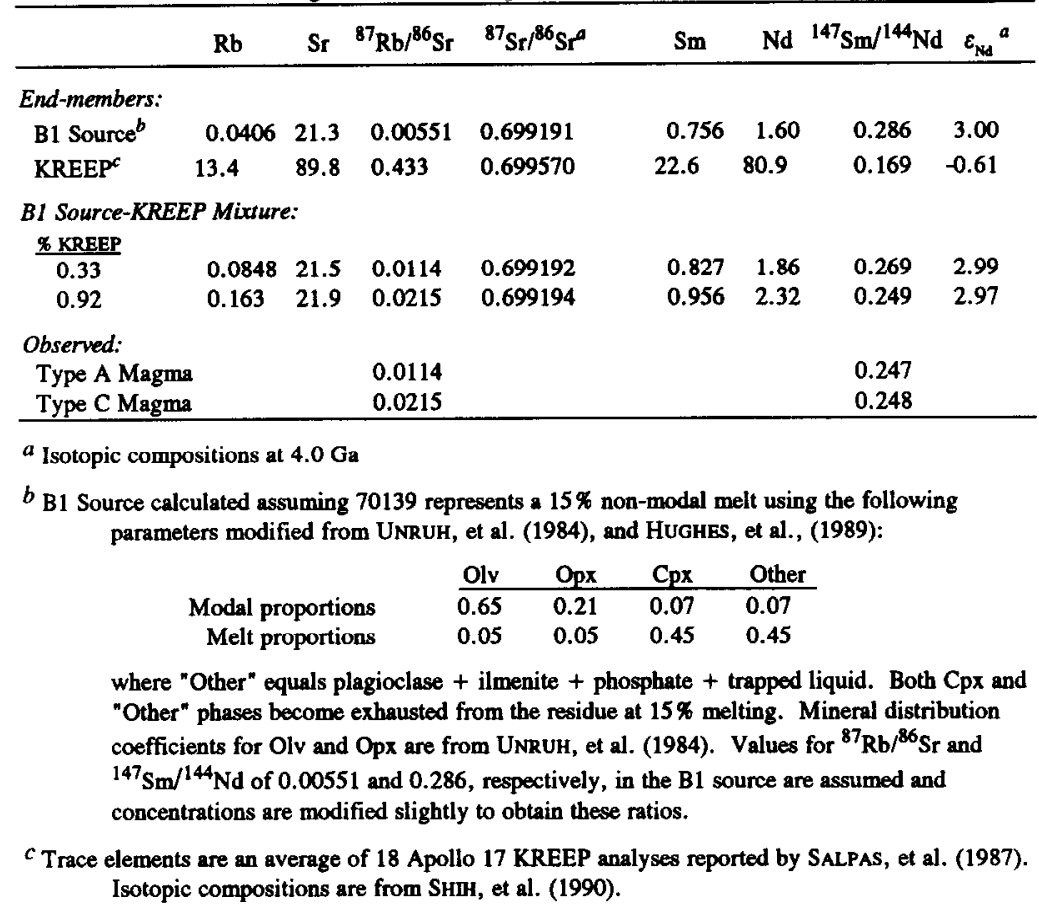

a geochemical process is required which is capable of imparting an up to four-fold increase in the $\mathrm{Rb} / \mathrm{Sr}$ ratio of Type $\mathrm{C}$ source region relative to Type $\mathrm{B} 1$ source region without a concomitant modification of REE ratios.

Strontium and neodymium arguments considered together help to establish the nature of the event which affected the $\mathrm{Sr}$ isotopic systematics of Types A and C mantle sources at 4.0 Ga. KREEPy basaltic magmatism identified at the Apollo 17 site occurred at the same time that high-Ti mare basalt sources were modified (COMPSTON et al., 1975; SHIH et al., 1990). Ages between 4.01 and 4.13 have been reported with $\mathrm{I}(\mathrm{Sr})$ of 0.69954 to 0.69960 and $\epsilon_{\mathrm{Nd}}$ of -0.61 (SHIH et al., 1990). Although it is possible that injection of a KREEP magmatic component into the original LIL- and LREE-depleted cumulate source region may have caused some modification, it is difficult to reconcile both $\mathrm{Sr}$ and $\mathrm{Nd}$ isotopic data through a KREEP mixing model. To illustrate these inconsistencies, $\mathrm{Rb}, \mathrm{Sr}, \mathrm{Sm}$, and $\mathrm{Nd}$ contents for unmodified $B 1$ source are estimated in Table 4 . These concentrations are poorly constrained; however, they should be reasonable enough to model the effects of addition of KREEP. Because the abundances of these elements are so low in the B1 source and so high in KREEP, addition of only 0.33 and $0.92 \%$ of the KREEP endmember is capable of reproducing ${ }^{87} \mathrm{Rb} /{ }^{86} \mathrm{Sr}$ ratios assumed for Types $A$ and $C$ source regions. Even though isotopic compositions of the two components are quite different, the isotopic compositions of the mixed sources are not noticeably shifted from that of the B1 source due to the very small amounts of KREEP added. However, the effect of this mixing model on the ${ }^{147} \mathrm{Sm} /{ }^{144} \mathrm{Nd}$ is sufficient to cause a substantial deviation in the evolution of $\mathrm{Nd}$ isotopes during the 270 to $330 \mathrm{Ma}$ between source modification and melt generation (dotted lines, Fig. 10c). Not only should the $\epsilon_{\mathrm{Nd}}$ values in the Types $\mathrm{A}$ and $\mathrm{C}$ sources be lowered from around +6.6 to +5.4 and +4.5 , respectively, but also, the higher proportion of KREEP added to the Type $C$ source should cause a dispersion of $\epsilon_{\mathrm{Nd}}$ values in Types $A$ and $C$ sources with time. Instead, the isotopic composition of both sources are nearly identical and lie along the Type B1 source evolution path. The Nd isotopic systematics in Types A, B1, and C basalts combined with the LREE-enriched patterns common to KREEP-rich rocks create a fundamental problem in all KREEP-mixing models regardless of specific choices for either original mantle cumulate or KREEP compositions. Similar arguments can be made involving small degrees of partial melting either added to or subtracted from the mantle cumulates. Although small amounts of melting will cause fractionation of $\mathbf{R b}$ from $\mathrm{Sr}$, this process is also very effective at fractionating $\mathrm{Nd}$ from $\mathrm{Sm}$.

Other, more $\mathrm{Rb} / \mathrm{Sr}$-enriched magmatic components which could have been mixed into the original cumulate source are either immiscible granite melts (RUTHERFORD et al., 1976; SHIH et al., 1985; TAYLOR et al., 1980; WARREN et al., 1983) or a hypothetical K-Fraction melt derived through silicate liquid immiscibility in cvolved KREEP (NEAL and TAYLOR, 1989). These types of K-rich magmas have extremely high $\mathrm{Rb}$ abundances and $\mathrm{Rb} / \mathrm{Sr}$ ratios, on the order of 100-200 ppm and 1, respectively. As a consequence, only a very minute amount of this material is required (less than $0.1 \%$ ) to elevate $\mathrm{Rb} / \mathrm{Sr}$ ratios in Types $\mathrm{A}$ and $\mathrm{C}$ source regions. Although these materials have LREE-enriched patterns similar to KREEP, the somewhat lower REE abundances along with the very low mixing proportions may result in only negligible changes in the ${ }^{147} \mathrm{Sm} /{ }^{144} \mathrm{Nd}$ of the hybrid sources. Therefore, these components are potentially capable of imparting significant $\mathrm{Rb} / \mathrm{Sr}$ modification without substantial $\mathrm{Sm} / \mathrm{Nd}$ ef- 
fects. However, the viscosity of these highly polymerized magmas (approximately $3 \times 10^{4}$ poise; NEAL and TAYLOR, 1989) make it difficult to envisage a mechanism of physically mixing the very small amounts of infiltration required to modify Types $A$ and $C$ sources.

Another mechanism capable of modifying the original mantle cumulates involves mobilizing $\mathrm{Rb}$ and other volatile metals preferentially to incompatible, but refractory, elements such as the REEs. The presence of volatile elements enriched on the surfaces of lunar glass spheres, thought to be of pyroclastic origin, has been interpreted as evidence for the volatile transport (especially as halogen complexes) of metals (CHOU et al., 1975; MEYER et al., 1975). DiCKINSON et al. (1989) have proposed that halogen-rich vapors were responsible for redistributing $\mathrm{Ge}$ within the lunar interior resulting in a form of mantle metasomatism. Their model speculates that volatile elements, including $\mathrm{Ge}$, were leached from wall rocks by $\mathrm{F}$ - and $\mathrm{Cl}$-rich fluids originating from outgassing of the lunar interior. Volatile metals, complexed with halogens, were transported outward until they encountered more-siliceous, $\mathrm{Na}$ - and K-rich magmas (i.e., urKREEP) where the halogen complexes were then resorbed into the KREEPy magmas due to the higher solubility of $\mathrm{Cl}$ and $\mathrm{F}$ in alkaline silicate liquids. A similar gas/fluid transport model can be invoked to explain the $\mathrm{Rb} / \mathrm{Sr}$ differences between Apollo 17 mare basalt sources. The ability of volcanic gases to transport volatile metals has bcen shown at numerous active terrestrial vents (ZOLLER et al., 1983; SYMONDS et al., 1987; CROWE et al., 1987). Alkali metals are highly enriched in these gas and sublimate samples relative to both their abundances in the associated silicate melts, as well as to Sr and REE abundances within the same volcanic gases. In typical terrestrial volcanic gases where $\mathrm{Cl}$ has a higher fugacity relative to $\mathrm{F}$, the alkali metals $\mathrm{Cs}, \mathrm{Rb}, \mathrm{K}$, and $\mathrm{Na}$, are all stable as chloride complexes rather than as $\mathrm{F}, \mathrm{Br}, \mathrm{OH}$, elemental, or other gas species (SYMONDS and REED, 1991). Therefore, it is conceivable that $\mathrm{Cl}$-rich fluids, derived through outgassing of the lunar interior, or through final crystallization of KREEPy magmas emplaced at mantle-source depths, were capable of leaching and transporting substantial amounts of $\mathrm{Rb}$ with little or no mobilization of either $\mathrm{Sr}$ or the REEs. Although REEs may be fractionated by this process, the absolute abundances of REEs transported by these fluids will most likely be small relative to the amount of $R b$ in solution. It is also probable that $\mathrm{Cl}$-rich fluids have very low viscosity, allowing even small amounts of this geochemical component to infiltrate into the original mantle cumulates.

Processes involving halogen-rich metasomatism provide an attractive means of explaining the disruption of the $\mathbf{R b}$ Sr system in Apollo 17 high-Ti basalts while leaving the SmNd system intact. Equally important, it also allows modification of the $\mathrm{Rb} / \mathrm{Sr}$ ratios without altering the ${ }^{87} \mathrm{Sr} /{ }^{86} \mathrm{Sr}$ compositions within the different sources so that a common $\mathrm{I}(\mathrm{Sr})$ at $4.02 \mathrm{Ga}$ remains well defined. Further evidence for a metasomatic origin for the $\mathrm{Rb} / \mathrm{Sr}$ heterogeneities may be recorded by $\mathrm{Ge}$ concentrations, which are three times higher in Type $C$ basalts relative to the other Apollo 17 magma types (DICKINSON et al., 1989). Since Ge bulk distribution coefficients are close to unity in mantle assemblages, abun- dances measured in basalts should be representative of their mantle sources (DICKINSON et al., 1989). The observed Ge disparity may have been introduced at the same time that $\mathrm{Rb} / \mathrm{Sr}$ ratios were modified, and may be linked, in some manner, to the similar-aged, Ge-enriched KREEPy basalts sampled at the Apollo 17 site. Ultimately, a fluid-infiltration model will require explanations for the mechanisms controlling the precipitation of transported metals from these fluids, as well as a reason for the progressive increase of fluid contributions into Types $\mathrm{A}$ and $\mathrm{C}$ source regions, respectively. Although details of lunar metasomatism are not yet clear, we speculate that this type of process played an important role in establishing the geochemical and subsequent isotopic heterogeneities observed in Apollo 17 high-Ti mare basalts.

\section{CONCLUSIONS}

Combined $\mathrm{Sr}$ and Nd isotopic studies of well-documented mare basalt suites offer the potential to refine details of basalt chronology and petrogenesis which are not wholly apparent from geochemical or single-system isotopic studies. In the present case, previously defined geochemical types of Apollo 17 high-Ti basalt (Types A, B1, B2, and C) exhibit slight differences in age which help to establish a geochemical stratigraphy, as well as subtle variations in initial isotopic compositions which permit characterization of different styles of magmatic evolution, distinction of source heterogeneities, and models for the geochemical histories of cumulate sources.

Two new internal $\mathrm{Sr}$ and $\mathrm{Nd}$ isochron ages presented in this study do not allow resolution between Type $A$ and Type B1 eruptive ages $(3.75 \pm 0.07 \mathrm{Ga}$ for 71359 , and $3.71 \pm 0.12$ Ga for 70139 , respectively) given the level of errors associated with regression calculations and the uncertainty surrounding the choice of $\mathrm{a}^{87} \mathrm{Rb}$ decay constant. However, utilization of the larger Apollo 17 mare basalt chronological data set offers the potential for reducing the uncertainties in average ages for the different chemical groups. Statistical treatment of all available Apollo 17 mare basalt dates suggests a weighted average age of volcanism of $3.72 \pm 0.04 \mathrm{Ga}$. However, if the dated basalts are classified on the basis of chemical criteria, a resolvable difference in ages between Types $\mathrm{A}(3.75 \pm 0.02$ $\mathrm{Ga}, \mathrm{N}=4)$ and Types $\mathrm{B} 1 / \mathrm{B} 2(3.69 \pm 0.02 \mathrm{Ga}, \mathrm{N}=3)$ is observed (Fig. 4). Type $\mathrm{C}$ basalts cannot be placed into this present chronological sequence with any certainty given the available data. Therefore, Apollo 17 mare basalt volcanism was dominated by early eruptions of Type A magmas, whereas later, magmatism consisted predominantly of Type B1/B2 magmas. Without the ability to clearly resolve age differences between individual flows, the nature of the transition between early and late magmatism remains unclear. Eruption of mare basalts may have been a more-or-less continuous event lasting for a period of 70 to $150 \mathrm{Ma}$ and implying that Types $A$ and B1/B2 magmas may have been produced contemporaneously over at least part of this age interval. Conversely, generation of Types A and B1/B2 magmas may have been temporally discrete with a substantial time hiatus separating generation and eruption of the two magma types. The ability to discriminate between these two eruptive scenarios has important implications for mechanisms of melt generation and may be addressed by additional dating of well-characterized samples. 
Whole-rock isotopic results confirm previous petrogenetic hypotheses which proposed that compositional variations within Types A, B1, and C geochemical groups can be explained by closed-system fractional crystallization of observed microphenocrystic phases (NEAL et al., 1990a). In contrast, Type B2 lavas exhibit a wide range of intra-group isotopic variation. Observed variations in initial isotopic composition cannot be ascribed to a simple two-component mixing model and are therefore qualitatively explained by assimilation of several isotopically distinct crustal components during transit of magmas to the surface. Recognition of assimilation-fractional crystallization processes in Type B2 magmas may eliminate much of the need for previously proposed models invoking variable degrees of partial melting to explain the range of $\mathrm{La} / \mathrm{Sm}$ in Apollo 17 magmas (SHIH et al., 1975; WARNER et al., 1979).

Subtle variations in isotopic compositions observed between Types A, B1, and C magmas are best explained by heterogeneities within the source regions for each basalt type. Source heterogeneities have been proposed previously on the basis of geochemical data (SHIH et al., 1975; WARNER et al., 1975, 1979; RHODES et al., 1976; NEAL et al., 1990a); however, present isotopic data allow constraints to be placed on the geochemical history of the Apollo 17 mantle sources. Whole-rock $\mathrm{Sr}$ data preserve a very well-defined isochron age of $4.02 \pm 0.05 \mathrm{Ga}\left(\lambda^{87} \mathrm{Rb}=1.42 \times 10^{-11} \mathrm{yr}^{-1}\right)$ and initial $\mathrm{Sr}$ isotopic composition of $0.699191 \pm 0.000012$. Although minor melting-induced modification of ${ }^{87} \mathrm{Rb} /{ }^{86} \mathrm{Sr}$ ratios cannot be completely dismissed, cumulative isotopic evidence, plus the presence of similar-aged KREEPy basalts at the same site, lead us to place geological importance in the whole-rock Sr isochron age. This date is interpreted to represent the last time at which the source regions for Types A, B1, and C magmas contained a common $\mathrm{Sr}$ isotopic composition resulting from the closed-system growth of radiogenic $\mathrm{Sr}$ in the LIL- and LREE-depleted mantle cumulates which crystallized around $4.4 \mathrm{Ga}$ from the lunar magmasphere. In contrast, whole-rock Nd data from Types $\mathrm{A}, \mathrm{B} 1$, and $\mathrm{C}$ basalts define an isochron age of $3.79 \pm 0.15 \mathrm{Ga}$ which is within error of the eruptive ages. This observation requires strong similarities in $\mathrm{Nd}$ isotopic compositions between the three groups and indicates that the $\mathrm{Sm}-\mathrm{Nd}$ systems were not similarly disturbed around $4.0 \mathrm{Ga}$. Although KREEP magmatism with ages between 4.01 and $4.13 \mathrm{Ga}$ has been identified at the Apollo 17 site (COMPSTON et al., 1975; SHIH et al., 1990), combined Sr and $\mathrm{Nd}$ isotopic data are not consistent with KREEP-cumulate mixing models. Instead, a mixing component with higher $\mathbf{R b}$ abundances relative to $\mathrm{Sr}$ and the REEs is required. Although lunar granite or the "K-fraction" of KREEP (NEAL and TAYLOR, 1989) are potential candidates, we prefer a model of mantle metasomatism involving halogen-rich fluids derived either through outgassing of the lunar interior or through final crystallization of KREEPy magmas emplaced nearby. These types of fluids are likely to be efficient at mobilizing volatile metals, such as $R b$, but much less capable of transporting either $\mathrm{Sr}$ or the more-refractory REEs. This type of process is capable of explaining the inhomogeneous introduction of $\mathrm{Rb}$ into an originally homogeneous Apollo 17 high-Ti mare basalt source region at around the same time that KREEP magmatic activity occurred at the Apollo 17 site. After alkali metasomatism, Sr isotopic compositions in the different source regions evolved divergently as a response to modified $\mathrm{Rb} / \mathrm{Sr}$ ratios, while $\mathrm{Sm} / \mathrm{Nd}$ remained undisturbed and Nd isotopic evolution within each source remained parallel until mare basalts were generated around 3.7 Ga. Further geochemical investigation of volatile element abundances within these three magma types may provide additional support for this metasomatic model.

Acknowledgments - We are grateful for the expeditious efforts of the LAPST committee and the curatorial staff at Johnson Space Center for rapid allocation and processing of the requested samples. This study was supported through NASA grant NAG9-62 to L. A. Taylor. The University of Michigan Radiogenic Isotope Geochemistry Lab was funded through NSF grants EAR-G-8616061, -8720564, and -8804072 to A. N. Halliday during the period of data collection. Thoughtful reviews by G. Ryder and L. E. Nyquist are greatly appreciated and helped improve the quality of this paper.

Editorial handling: G. Faure

\section{REFERENCES}

BINDER A. B. (1985) The depths of the mare basalt source region. Proc. 15th Lunar Planet. Sci. Conf.; J. Geophys. Res. 89, C396C404.

Brown G. M., Peckett A., Emeleus C. H., Phillups R., and PiN. SENT R. H. (1975) Petrology and mineralogy of Apollo 17 mare basalts. Proc. 6th Lunar Sci. Conf., 1-13.

CARLSON R. W, and Lugmair G. W. (1979) Sm-Nd constraints on early lunar differentiation and the evolution of KREEP. Earth Planet. Sci. Lett. 45, 123-132.

Chou C.-L., BoYNTON W. V., SUNDBerg L. L., and WASSON J. T. (1975) Volatiles on the surface Apollo 15 green glass and traceelement distributions among Apollo 15 soils. Proc, 7 th Lunar Sci. Conf., 1701-1727.

COMPSTON W., FOSTER J. J., and GRAY C. M. (1975) Rb-Sr ages of clasts from within Boulder 1, Station 2, Apollo 17. The Moon 14, 445-462.

Crowe B. M., Finnegan D. L., Zoller W. H., and Boynton W. V. (1987) Trace element geochemistry of volcanic gases and particles from 1983-1984 eruptive episodes of Kilauea Volcano. J. Geophys. Res. 92, 13, 708-713, 714.

DePaOlo D. J. and WASSERBURG G. J. (1976) Nd isotopic variations and petrogenetic models. Geophys. Res. Lett. 3, 249-252.

Dickinson T., TAYLOR G. J., KeIL K., and BLD R. W. (1989) Germanium abundances in lunar basalts: Evidence of mantle metasomatism? Proc. 19th Lunar Planet. Sci. Conf., 189-198.

DYMeK R. F., AlbeE A. L., and CHODOS A. A. (1975) Comparative mineralogy and petrology of Apollo 17 mare basalts: Samples 70215, 71055, 74255, and 75055. Proc. 3rd Lunar Sci. Conf., 4977.

EVENSEN N. M., MURTHY V. R., and COSCIO M. R., JR. (1973) RbSr ages of some mare basalts and the isotopic and trace element systematics in lunar fines. Proc. 4th Lunar Sci. Conf., 1707-1724.

Green D. H., Ringwood A. E., Hibberson W. O., and WARE N. G. (1975) Experimental petrology of Apollo 17 mare basalts. Proc. 6th Lunar Sci. Conf., 871-893.

Halliday A. N., Mahood G. A., Holden P., Metz J. M., DemPSTER T. J., and DAVIDSON J. P. (1989) Evidence for long residence times of rhyolitic magma in the Long Valley magmatic system: the isotopic record in precaldera lavas of Glass Mountain. Earth Planet. Sci. Lett. 94, 274-290.

HORN P., JESSBERGER E. K., KIRSTEN T., and RICHTER H. (1975) ${ }^{39} \mathrm{Ar}-{ }^{40} \mathrm{Ar}$ dating of lunar rocks: Effects of grain size neutron irradiation. Proc. 6th Lunar Sci. Conf., 1563-1591. 
Hughfs S. S., Delano J. W., and SChmmt R. A. (1989) Petmgenetic modeling of 74220 high-Ti orange volcanic glasses and the Apollo 11 and 17 high-Ti mare basalts. Proc. 19th Lunar Planet. Sci. Conf., 175-188.

Huneke J. C., Jessberger E. K., Podosek F. A., and Wasserburg G. J. (1973) ${ }^{39} \mathrm{Ar} /{ }^{40} \mathrm{Ar}$ measurements in Apollo 16 and 17 samples and the chronology of metamorphic and volcanic activity in the Taurus-Littrow region. Proc. 4th Lunar Sci. Conf., 1725-1756.

Kesson S. E. (1975) Mare basalts: Melting experiments and petrogenetic interpretations. Proc: 6th Lunar Sci. Conf., 921-944.

KIRSTEN T. and HORN P. (1974) Chronology of Taurus-Littrow region-III: Ages of mare basalts and highland breccias and some remarks about the interpretation of lunar highland rock ages. Proc. Sth Lunar Sci. Conf., 1451-1475.

KirSTEN T., Horn P., and Heymann D. (1973) Chronology of Taurus-Littrow region I: Ages of two major rock types from the Apollo 17 site. Earth Planet. Sci. Lett. 20, 125-130.

LoNGi J., Walker D., Grove T. L., STOLPER E. M., and Hays J. F. (1974) The petrology of Apollo 17 mare basalts. Proc. 5th Lunar Sci. Conf., 447-469.

LUDWIG K. R. (1990) ISOPLOT: A plotting and regression program for radiogenic-isotope data, for IBM-PC compatible computers, version 2.01. USGS Open-file Rept. 88.557.

LugMaIR G. W., SCHFININ N. B., and MARTI K. (1975) Sm-Nd age and history of Apollo 17 basalt 75075: Evidence for early differentiation of the lunar exterior. Proc. 6th Lunar Sci. Conf., 1419 1429.

MEYer C., JR., MCKay D. S., ANDERSON D. H., and Butler P., JR. (1975) The source of sublimates on the Apollo 15 green and Apollo 17 orange glass samples. Proc. Gih Lunar Sci. Conf., 16731699.

MinSTER J.-F., BiRCK F.-L., and ALLEGre C. J. (1982) Absolute age of formation of chondrites studied by the ${ }^{87} \mathrm{Rb}-{ }^{86} \mathrm{Sr}$ method. Nature 300, 414-418.

Murali A. V., Ma M.-S., Schmitt R. A., Warner R. D., KeIL K., and TAYLOR G. J. (1977) Chemistry of 30 Apollo 17 rake basalts; 71597 a product of partial olivine accumulation (abstr.). Lunar Sci. VIII, 703-705.

MURTHY V. R. and Coscio M. R., JR. (1976) Rb-Sr ages and isotopic systematics of some Serenitatis mare basalts. Proc. 7th Lunar Sci. Conf., 1529-1544.

NEAL C. R. and TAYLOR L. A. (1989) Metasomatic products of the lunar magma ocean: The role of KREEP dissemination. Geochim. Cosmochim. Acta 53, 529-541.

NeAl C. R., TAYlor L. A., Hughes S. S., and Schmitt R. A. (1989) Apollo 17 high-Ti basalt petrogenesis: An integrated approach using whole-rock major and trace element analyses (abstr.). Lunar Planet. Sci. XX, 776-777.

Neal C. R., Taylor L. A., Patchen A. D., Hughes S. S., and SCHMITT R. A. (1990a) The significance of fractional crystallization in the petrogenesis of Apollo 17 Type A and B high-Ti basalts. Geochim. Cosmochim. Acta 54, 1817-1833.

Neal C. R., Paces J. B., TAYLor L. A., Hughes S. S., and SChmitt R. A. (1990b) Two new Type C basalts: Petrogenetic implications for source evolution and magma genesis at the Apollo 17 site. Lunar Planet. Sci. XXI, 855-856.

Nyquist L. E., Bansal B. M., WiesmanN H., and JaHN B.-M. (1974) Taurus-Littrow chronology: Some constraints on early lunar crustal development. Proc. 5th Lunar Sci. Conf., 1515-1539.

NYQuIST L. E., BANSAL B. M., and WIESMANN H. (1975) Rb-Sr ages and initial ${ }^{87} \mathrm{Sr} /{ }^{86} \mathrm{Sr}$ for Apollo 17 basalts and KREEP basalt 15386. Proc. 6th Lunar Sci. Conf., 1445-1465.

NYQUIST L. E., BANSAL B. M., and WIESMANN H. (1976) Sr isotopic constraints on the petrogenesis of Apollo 17 mare basalts. Proc. 7 th Lunar Sci. Conf., 1507-1528.

NYQuist L. E., BANSAL B. M., WoOden J. L., and WIESMANN H. (1977) The Sr-isotopic constraints on the petrogenesis of Apollo 12 mare basalts. Proc. 8th Lunar Sci. Conf., 1385-1415.

NYquisT L. E., SHH C.-Y., WOODEN J. L., BANSAL B. M., and WIESMANN H. (1979) The Sr and Nd isotopic record of Apollo 12 basalts: Implications for lunar geochemical evolution. Proc. 10th Lunar Planet. Sci. Conf., 77-114.
NYQUIST L. E., RFIMOID W. U., BOGARD D. D., WOODEN J. L., BANSAL B. M., WIESMANN H., and SHIH C.-Y. (1981) A comparative $\mathrm{Rb}-\mathrm{Sr}, \mathrm{Sm}-\mathrm{Nd}$, and K-Ar study of shocked norite 78236 : Evidence of slow cooling in the lunar crust? Proc. 12th Lunar Planet. Sci. Conf. B, 67-97.

Nyquist L. E., Bansal B. M., Shih C.-Y., Wiesmann H., Wooden J. L., and TAKEDA H. (1986) Rb-Sr and Sm-Nd internal isochron ages of a subophitic basalt clast from the Y75011 eucrite. $J$. Geophys. Res. 91, B8, 8137-8150.

PaPike J. J., Bence A. E., and Lindsley D. H. (1974) Mare basalts from the Taurus-Littrow region of the Moon. Proc. 5th Lunar Sci. Conf., 471-504.

Papike J. J., Hodges F. N., Bence A. E., Cameroon M., and RHODES J. M. (1976) Mare basalts: Crystal chemistry, mineralogy, and petrology. Rev. Geophys. Space Phys. 14, 475-540.

Philpotts J. A. and SCHNETZler C. C. (1970) Apollo 11 lunar samples: $\mathrm{K}, \mathrm{Rb}, \mathrm{Sr}, \mathrm{Ba}$ and rare-earth concentrations in some rocks and separated phases. Proc. Apollo 1/ Lunar Sci. Conf., 14711486.

Rhodes J. M., Hubbard N. J., WiesmanN H., Rodgers K. V., BRANNON J. C., and BANSAL B. M. (1976) Chemistry, classification, and petrogenesis of Apollo 17 mare basalts. Proc. 7th Lunar Sci. Conf., 1467-1489.

Rutherford M. J., Hess P. C., Ryerson F. J., CAMPBell H. W., and DICK P. A. (1976) The chemistry, origin and petrogenetic implications of lunar granite and monzonite. Proc. 7th Lunar Sci. Conf., 1723-1740.

RYDER G. (1990) A distinct variant of high-titanium mare basalt from the Van Serg core, Apollo 17 landing site. Meteroritics 25, 249-258.

SALPAS P. A., TAYLOR L. A., and LindSROM M. M. (1987) Apollo 17 KREEPy basalts: Evidence for Nonuniformity of KREEP. Proc. 17th Lunar Planet. Sci. Conf.; J. Geophys. Res. 92, B4, E340E348.

SCHAEFFER G. A. and SCHAEFFER O. A. (1977) ${ }^{39} \mathrm{Ar}^{-40} \mathrm{Ar}$ ages of lunar rocks. Proc. 8th Lunar Sci. Conf., 2253-2300.

Shih C.-Y., Haskin L. A., Wiesmann H., Bansal. B. M., and BRANNON J. C. (1975) On the origin of high-Ti mare basalts. Proc. 6th Lunar Sci. Conf. 1255-1285.

SHiH C.-Y., NYQuist L. E., Bogard D. D., WOODEN J. L., BaNSAL B. M., and WIESMANN H. (1985) Chronology and petrogenesis of a 1.8 g lunar granite clast: 14321,1062 . Geochim. Cosmochim. Acta 49, 411-426.

SHIH C.-Y., NYQUist L. E., BOG.ARD D. D., BANSAL B. M., WiesMANN H., JOHNSON P., SHERVAIS J. W., and TAYLOR L. A. (1986) Geochronology and petrogenesis of Apollo 14 very high Potassium mare basalts. Proc. 16th Lunar Planet. Sci. Conf.; J. Geophys. Res., 91, B4, D214-D228.

ShiH C.-Y., BANSAL B. M., and WIESMANN H. (1990) Rb-Sr and Sm-Nd isotopic studies of an Apollo 17 KREEPy basalt (abstr.). Lunar Planet. Sci. XXI, 1148-1149.

STEIGER R. H. and JÄEGER E. (1977) Subcommission on geochronology: Convention on the use of decay constants in geo- and cosmochronology. Earth Planet. Sci. Lett. 36, 359-362.

Stettler A., EberhardT P., Geiss J., GROGler N., and MAURER P. (1973) ${ }^{9} \mathrm{Ar}-{ }^{40} \mathrm{Ar}$ ages and ${ }^{37} \mathrm{Ar}-{ }^{38} \mathrm{Ar}$ exposure ages of lunar rocks. Proc. 4th Lunar Sci. Conf., 1865-1888.

SYMONDS R. B. and REED M. H. (1991) Calculation of multicomponent chemical equilibria in gaseous-solid-liquid systems, Part II: Thermochemical data and applications to studies of high-temperature volcanic gases with examples from Mount St. Helens. Amer. J. Sci. (in press.).

Symonds R. B., Rose W. I., Reed M. H., Lichte F. E., and Fin. NEGAN D. L. (1987) Volatilization, transport and sublimation of metallic and non-metallic elements in high temperature gases at Merapi Volcano, Indonesia. Geochim. Cosmochim. Acta 51, 20832101.

TaYlor G. J., WARner R. E., KeIL K., MA M.-S., and SChMitT R. A. (1980) Silicate liquid immiscibility, evolved lunar rocks and the formation of KREEP. In Proc. Conf. Lunar Highlands Crust (eds. J. J. PAPIKE and R. B. MERRILL), pp. 339-352. Pergamon Press. 
TAYLOR S. R. (1982) Planetary Science: A Lunar Perspective. Houston: Lunar Planet. Inst.

Tera F., Papanastassiou D. A., and Wasserburg G. J. (1973) A lunar cataclysm at $-3.95 \mathrm{AE}$ and the structure of the lunar crust. Lunar Science IV, 723-725. Lunar Institute, Houston.

Tera F., Papanastassiou D. A., and Wasserburg G. J. (1974) Isotopic evidence for a terminal lunar cataclysm. Earth Planet. Sci. Lett. 22, 1-21.

TitTERINGTON D. M. and Halliday A. N. (1979) On the fitting of parallel isochrons and the method of maximum likelihood. Chem. Geol. 26, 183-195.

TURNER G. and CADOGEN P. H. (1975) The history of lunar bombardment inferred from 40Ar-39Ar dating of highland rocks. Proc. 6th Lunar Sci. Conf., 1509-1538.

TuRner G., CADOGAN P. H., and YONGE C. J. (1973) Argon selenochronology. Proc. 4th Lunar Sci. Conf., 1889-1914.

Unruh D. M., Stille P., Patchett P. J., and Tatsumoto M. (1984) Lu-Hf and Sm-Nd evolution in lunar mare basalts. Proc. 14th Lunar Planet. Sci. Conf.; J. Geophys. Res. 89, B459-B477.
Warner R. D., Keil K., Prinz M., Laul J. C., Murali A. V., and SCHMITT R. A. (1975) Mineralogy, petrology and chemistry of mare basalts from Apollo 17 rake samples. Proc. 6th Lunar Sci. Conf., 193-220.

Warner R. D., Taylor G. J., Conrad G. H., Northrop H. R., BARKer S., KeIL K., MA M.-S., and SCHMITT R. A. (1979) Apollo 17 high-Ti mare basalts: New bulk compositional data, magma types and petrogenesis. Proc. 10th Lunar Planet. Sci. Conf., 225247.

WARREN P. H. (1985) The magma ocean concept and lunar evolution. Ann. Rev. Earth Planet. Sci. 13, 201-240.

WARREN P. H., TAYLOR G. J., KeIL. K., SHIRLEY D. N., and WASSON J. T. (1983) Petrology and chemistry of two "large" granite clasts from the Moon. Earth Planet. Sci. Lett. 64, 175-185.

YORK D. (1969) Least-squares fitting of a straight line with correlated errors. Earth Planet. Sci. Lett. 5, 320-324.

Zoller W. H., Parrington J. R., and Phelan Kotra J. M. (1983) Iridium enrichment in airborne particles from Kilauea Volcano: January 1983. Science 222, 1118-1121. 